\title{
Effect of Self-Curing Admixture on Concrete Properties in Hot Climate
}

\author{
Joseph P. Rizzuto', Mounir Kamal' ${ }^{2}$, Hanaa Elsayad ${ }^{3}$, Alaa Bashandy ${ }^{2}$, Zeinab Etman², \\ Mohamed N. Aboel Roos ${ }^{2}$, and Ibrahim G. Shaaban ${ }^{1}$ \\ ${ }^{1}$ Civil Engineering and Built Environment, School of Computing and engineering, University of West London, \\ UK \\ ${ }^{2}$ Civil Engineering Department, Faculty of Engineering, Menoufia University, Egypt, \\ ${ }^{3}$ Civil Engineering Department, Faculty of Engineering, Shoubra, Benha University, Egypt
}

\section{Highlights}

- PEG 400 admixture was used in concrete mixes produced for hot weather conditions

- Dry materials, mixing water and curing temperatures simulated hot weather

- Properties of PEG samples were found to be superior to the control concrete

- Results cannot to attributed only to prevention of pore water escape by PEG 400

- A proposal was made to explain the results based on information from the literature

\begin{abstract}
Hot climates prevail in many regions of the globe. The average summer temperature of hot arid areas is in the range of $40-50{ }^{\circ} \mathrm{C}$ with temperatures exceeding these values under direct solar radiation. Curing concrete in these regions may be challenging due to limited availability of suitable water for curing and/or rapid loss of curing water by evaporation. For many years self-curing admixtures were recommended as an alternative to water curing, however, limited studies have been conducted on their performance in hot weather conditions. In this investigation, the effects of a hot climate on the fresh and hardened properties of self-curing (SC) concrete and normal conventional concrete (NC) in hot weather were studied. A watersoluble polymer self-curing agent, polyethylene glycol (PEG 400), was added to the SC mixes. The testing parameters were concrete dry materials $\left(25\right.$ or $\left.50^{\circ} \mathrm{C}\right)$ and/or mix water temperatures $\left(5,20\right.$ or $\left.35^{\circ} \mathrm{C}\right)$ at the time of mixing. NC samples were continuously water cured at 25 or $50{ }^{\circ} \mathrm{C}$, whereas the SC ones were air cured at the same temperatures. The tested properties were workability, compressive strength, splitting tensile strength, and flexural strength. It was found that SC outperformed $\mathrm{NC}$ under varying conditions. The results could not be simply attributed to the retention of mix water by the self-curing admixture. A more comprehensive explanation for the observations is proposed.
\end{abstract}

Keywords: hot climates; self-curing concrete; concrete admixtures; mechanical properties

\section{INTRODUCTION}

Many challenges are associated with concrete production in hot climate conditions. Factors such as the high temperature of the ambient air, high wind speeds, low relative humidity and direct solar radiation lead to rapid water evaporation from the fresh concrete. This has a negative effect both the fresh and hardened concrete properties [1-4]. 
Almusallam [5] prepared samples at ambient temperatures of 30 and $45{ }^{\circ} \mathrm{C}$ in a special chamber. He reported higher casting temperatures lead to rapid compressive strength gain in the early ages, but at later ages the strength decreased. Kim et al. [6] explored the effect of curing temperature ranging from 10 to $50{ }^{\circ} \mathrm{C}$ by testing compressive and split tensile strength of samples prepared from different cements up to 28 days. They reported that the early strengths increased with the increase in temperature, but the later age strength decreased.

The reasons for the impaired performance of concrete in hot weather are rooted in the changes to the microstructure of concrete. Wang et al. [7] reported that elevated temperature curing, during the early ages, leads to deterioration of transition zone because the late hydration of cement is hindered. Zacak et al. [8] found that, the C-S-H layer formed during the accelerated hydration period is denser at $45^{\circ} \mathrm{C}$ than that formed during lower temperatures. Therefore, the diffusion of water and ions through this C-S-H layer is more difficult when it is formed at a higher temperature. Hence, further hydration of cement particles after final setting becomes more difficult. ElKhadiri et al. [9] studied the pore size distributions of samples cured at different temperatures (i.e. 4, 22, 40 and $85^{\circ} \mathrm{C}$ ). They argued that low initial rates of hydration, associated with temperatures below $22^{\circ} \mathrm{C}$, resulted in controlled precipitation of reaction products in interstitial space, raising the gel/space ratio and increasing the volume fraction of meso-pores (i.e. pore refinement). The mechanical strength is positively affected in these conditions. The reverse was observed for higher temperature hydration.

ACI 305.1-06 [10], limits the maximum fresh concrete temperature to 35OC. A number of techniques could be used to accomplish this including: "shading aggregate stockpiles, sprinkling water on coarse aggregate stockpiles, using chilled water for concrete production, substituting chipped or shaved ice for portions of the mixing water, and cooling concrete materials using liquid nitrogen". However, in developing countries, with low budget projects, it is not always possible to satisfy these requirements. Several standards [10-13], also consider that curing is one of the factors affecting concrete properties. The main types of curing can be divided into two groups. The first one includes frequent or continuous water application throughout hydration, in the form of steam, sprays, ponding or sawdust, sand, cotton mats and burlap. These are all known as saturated cover materials. The second group includes the form of curing that aims to preventing water loss from the concrete [14]. This can be achieved by applying membranes on the fresh concrete in the form of reinforced paper or plastic sheets [15], or by employing various methods of self-curing or internal curing [16-18] ACI.308R-01 [16] states that "internal curing refers to the process by which the hydration of cement occurs because of the availability of additional internal water that is not part of the mixing Water."

Bílek et al. [19] reviewed methods of self-curing concrete arguing that wet or water curing for long periods (e.g. 28 days) is impossible for a lot of construction processes. Vanisri [20] pointed out that self-curing mitigates curing problems due to human negligence, paucity of water in arid areas, inaccessibility of project sites, and is necessary in areas where the quality of water will adversely affect the characteristics of concrete. In many parts of the world fresh water is a costly material and there is a need to this preserve natural resource [21]. Self-curing chemicals such as water-soluble polyethylene glycol (PEG) were found to be effective in improving the physical properties of concrete such as water retention, water absorption and permeability [17]. In addition, internal curing provides sufficient water and proper spatial distribution, so that the all internal parts of the paste remain saturated and autogenous stress free [22]. The use of this admixture would allow for hydration to continue for the concrete to achieve the desirable properties.

Bashandy et al. [24], Chand et al. [23] and El-Dieb [15] studied the properties of mixes containing one or two types self-curing admixtures. However, their mixes were prepared and 
cured in laboratory conditions, and no variation in mixing materials or curing temperatures was applied. Assal [25], Negm El Din et al. [26], Madi et al. [27], and Kamal et al. [28] studied the effect of changing the mixing water and dry materials temperatures on the fresh and hardened properties of concrete. However, their mixes did not contain any self-curing admixtures.

Chand et al. [29] examined Grade 70 concrete samples with and without PEG 4000 self-curing admixture. They cured conventional samples in water or air at ambient temperature $\left(27^{\circ} \mathrm{C}\right)$ or at elevated temperature $\left(50^{\circ} \mathrm{C}\right)$, whereas the samples with PEG 4000 were air cured in the two temperatures. Chand et al. [21] studied the performance of different dosages of various types of self-curing admixtures in self-compacting concrete. Their mixes were subject to two curing conditions (i.e. room temperature at $27^{\circ} \mathrm{C}$ or elevated temperature in an oven at $60^{\circ} \mathrm{C}$ ). Mousa et al. [17] carried out an experimental study using two methods for self-curing (inclusion of LECA aggregates or the use of polyethylene-glycol of 200 molecular weight). Their samples were exposed to four curing regimes: air $\left(25^{\circ} \mathrm{C}\right)$ with relative humidity of approximately $65 \%$ for 28 days, air $\left(50{ }^{\circ} \mathrm{C}\right)$ for 28 days, renewable carbon dioxide $(5 \%)$ for 6 months, and wet/dry cycles in saline water ( $8 \%$ sodium chloride) for 6 months where each cycle equals to two weeks to study various durability aspects of the mixes. However, Chand el al. [29], Chand et al. [21] and Mousa et al. [17] did not vary the mix materials temperatures, and hence the fresh concrete temperature, at the time of preparing the mixes, was at laboratory standard conditions.

\section{RESEARCH SIGNIFICANCE}

Al-Martini and Nehdi (2007) [30] stressed the need to study the performance chemical admixtures in hot weather as most of the technical data was obtained at normal laboratory conditions.

The aim of this investigation is to compare the behaviour of self-curing (SC) concrete, containing PEG 400, and conventional (NC) concrete, when employed in hot weather conditions. It is in these conditions that there may be problems with controlling the temperature of mixing and/or curing water temperature or the temperature of the stockpiles of the dry mix ingredients. The main variables were: mixing water temperature $\left(5^{\circ} \mathrm{C}, 20^{\circ} \mathrm{C}\right.$ and $35^{\circ} \mathrm{C}$ ), dry concrete materials temperature $\left(25^{\circ} \mathrm{C}\right.$ and $\left.50^{\circ} \mathrm{C}\right)$, and curing temperature $\left(25^{\circ} \mathrm{C}\right.$ and $\left.50^{\circ} \mathrm{C}\right)$. $\mathrm{NC}$ was continuously water cured, whereas the SC mixes were air cured at these temperatures until the time of testing. The slump of the fresh concrete, along with the compressive, tensile and flexural strengths shall be measured to understand the effect of hot weather on the concrete properties with and without the PEG 400 self-curing admixtures. Combining these variables together in the current study covers the gap in the current published research regarding the performance of self-curing admixtures in hot climates.

\section{EXPERIMENTAL PROGRAM}

The experimental program was carried out in the Civil Engineering laboratory of Menoufia University, Egypt. The details of the materials used, concrete specimens, test methods and methodology are now discussed in the following sections.

\subsection{Materials}

The cement used was Ordinary Portland Cement (OPC) CEM I 52.2 N conforming to ES 47561 [31]. The fine aggregate was natural siliceous sand compliant with ASTM C-33 [32]. Tables 1 and 2 show the mechanical properties and grading of the fine aggregate. The coarse aggregate was natural dolomite with a maximum size of $10 \mathrm{~mm}$ satisfying ASTM C-33 [32] as shown in Tables 3 and 4. Clean potable water was used for mixing and curing. 
The chemical curing agent, PEG 400, was a strongly hydrophilic polymer, soluble in water, colourless, viscous, and of low-molecular-weight. Technical information provided by the manufacturer is shown in Table 5. This material is used in many applications including chemical and pharmaceutical industries [33].

\subsection{Concrete Specimens}

The concrete mixture was designed to provide a characteristic strength of $40 \mathrm{MPa}$ under standard conditions in accordance with BS 8500-1 [34]. A number of trial-mixes were made in order to achieve a suitable mix. The constituents of the mix are shown in Table 6 . The specimens used in this study to determine the strength of the self-curing concrete and conventional concrete were as follows:

Concrete cubes of $100 \mathrm{~mm}$ side length were used to determine the compressive strength.

Concrete cylinders of $150 \mathrm{~mm}$ diameter and $300 \mathrm{~mm}$ length were used to determine the splitting tensile strength.

Concrete prisms of a square section of $100 \mathrm{~mm}$ side length and $500 \mathrm{~mm}$ total length were used to determine the flexural strength.

To test the properties for each mix cured under each curing condition, three samples were prepared. All of the above specimens were made in steel moulds. An electric vibrator was used to compact the concrete and a trowel finish applied to the exposed surfaces.

\subsection{Sample Preparation and Curing}

Samples were prepared using chilled water having a temperature of $5^{\circ} \mathrm{C}$ as per the recommendations for hot weather concreting, using normal tap water at $20^{\circ} \mathrm{C}$, or heated water at $35^{\circ} \mathrm{C}$ to study the effect warm water in hot climates. In addition, the dry materials of concrete were mixed at the normal laboratory temperature of $25^{\circ} \mathrm{C}$ or heated in an electrical oven to $50^{\circ} \mathrm{C}$ to simulate hot stockpiles in building sites. The dry materials were heated for one hour and mixed immediately once removed from the oven.

Wet curing was conducted for NC samples whereas samples with self-curing compounds (SC) were cured in air. Two curing temperatures were employed, $25^{\circ} \mathrm{C}$ and $50^{\circ} \mathrm{C}$. The latter was to simulate curing in hot climates. The NC concrete samples were kept in their moulds for the first 24 hours after casting. They were then taken out of their moulds and immersed in clean water in tanks where the temperature was kept at $25^{\circ} \mathrm{C}$ and $50^{\circ} \mathrm{C}$ until testing. The SC specimens containing a chemical agent were also kept in their moulds for the first 24 hours. SC samples were then stripped from their moulds. These samples left to cure in laboratory air $\left(25^{\circ} \mathrm{C}\right)$ were sealed with aluminum foil to prevent surface drying. Oven cured samples were stored at a temperature of $50^{\circ} \mathrm{C}$ until testing.

\subsection{Test Procedures}

The slump test was carried out to control the plastic consistency of the fresh mixes. The test was carried out in accordance with BS EN 12350-2 [35]. Hardened concrete properties were obtained: compressive, splitting tensile, and flexure strengths. Flexural strength testing was carried out according to ASTM C348 [36].

\section{RESULTS AND DISCUSSION}

\subsection{Slump Results for the Test Mixes}

The values obtained from slump test for SC and NC mixes at different temperatures are 
recorded in Table 7.

It can be seen from the values in the table that for dry materials having a temperature of $25^{\circ} \mathrm{C}$, the slump values for SC mixes were slightly higher than those of NC mixes with a range of 6$14 \%$ depending on mixing water temperature. This is in line with the findings of Kushwaha and Parihar [37], who reported an increase of $8 \%$ in the slump values after adding $2 \%$ PEG 400 for a similar mix to that employed in the current investigation. Other researchers [38-40] reported higher increases in the slump values for mixes with the self-curing admixtures, however, in their mixes no account was made to reduce the mix water to keep the effective w/c constant. Knapen and Van Gemert [41] reported that water soluble polymers have a plasticizing, lubricating and air-entraining effect.

For dry materials at $50^{\circ} \mathrm{C}$, the PEG 400 admixture further enhanced the slump by causing an increase between 11-40\% compared to the conventional concrete mixes. The results indicate that PEG 400 self-curing admixture also acts as a workability enhancer especially at higher mix temperatures.

By comparing the slump results for mixes prepared when the dry materials temperature was $25^{\circ} \mathrm{C}$ to those at $50^{\circ} \mathrm{C}$, it can be seen that the slump values were reduced dramatically for the higher temperature by a range of $65-77 \%$ and $61-72 \%$ for $\mathrm{NC}$ and SC mixes, respectively. Therefore, the SC mixes were somewhat less susceptible to slump reduction at higher temperature compared to NC mixes. Ahmed, Khalil and Jumaa [42] prepared normal concrete mixes during different times of the day in the summer of Iraq, measuring fresh concrete temperature and slump. They reported that for fresh concrete temperatures of 34.1 and $46.6^{\circ}$ $\mathrm{C}$, the slump values were 100 and $40 \mathrm{~mm}$, respectively. This $60 \%$ reduction in slump with the increase in temperature of the fresh concrete is in line with the results of the current investigation.

\subsection{Results of the Compressive Strength Test}

A comparison between $\mathrm{NC}$ and $\mathrm{SC}$ concrete was conducted to investigate the performance of PEG 400 under normal and hot climate conditions. The compressive strength values are recorded in Tables 8 and 9.

\subsubsection{Effect of Inclusion of PEG 400 on the Compressive Strength of Concrete}

The inclusion of the self-curing admixture has resulted in an increase of compressive strength in all conditions. The percentage increase can be seen at Figure 1 for the dry materials at $25^{\circ} \mathrm{C}$, and at Figure 5 for dry materials at $50^{\circ} \mathrm{C}$. In Figure 1, with the dry materials temperature of $25^{\circ} \mathrm{C}$, the $\mathrm{SC}$ mixes exhibited strengths that were higher than the $\mathrm{NC}$ counterparts by 3.2-11.9 $\%$ for various mixing water temperatures and curing temperatures at 7 days of age. At the age of 28 days for the same conditions, the increases of strength were less at 1.3-9.1\%. Mousa et al. [43] studied mixes with and without polyethylene-glycol, prepared and cured in laboratory air at $25{ }^{\circ} \mathrm{C}$. They reported that the samples with $2 \%$ self-curing agent exhibited $32.5 \%$ compressive strength increase at 28 days compared to the samples without this admixture. In their study the inclusion of the self-curing agent had a more pronounced effect on the compressive strength, probably because their normal concrete mixes were air cured not water cured as in the current investigation. Chand el al. [23] studied samples with and without selfcuring compounds of two molecular weights (PEG 200 and PEG 4000) prepared and cured at room temperature. They reported that their mortar samples with $0.5 \%$ PEG 200 and $1.0 \%$ PEG 4000 , exhibited a 28-day compressive strength that is almost equal to the conventional wet cured concrete. Vaisakh et al. [44] water cured normal mixes and air cured mixes with PEG 400. They reported an increase of $5.41 \%$ in compressive strength due to the inclusion of PEG 400 in Grade 50 mixes. These reports are in line with the results of the current investigation. 
From Figure 2 it can be seen that when dry materials temperature was $50{ }^{\circ} \mathrm{C}$, the $\mathrm{SC}$ mixes exhibited far more superior strengths compared to $\mathrm{NC}$ counterparts as the increases were 77.2 $-90.9 \%$ and $44.4-81.5 \%$ at 7 and 28 days of age, respectively.

Several investigators $[15,45-48]$ found that self-curing compounds reduce water evaporation from concrete compared with conventional concrete leading to enhanced hydration and improved compressive strength. The mixes employed in these reports where prepared in laboratory conditions. Therefore, the results of the current investigation, where the dry materials temperatures were $25{ }^{\circ} \mathrm{C}$, are in line with the previous reports. However, the results of the current investigation, simulating hot site stockpiles at $50{ }^{\circ} \mathrm{C}$, gave new evidence that the performance of air cured mixes with self-curing admixture are enhanced in hot weather conditions, compared to mixes prepared in laboratory conditions. The reasons for this observation need further investigation and cannot be attributed to water retention only.

\subsubsection{Effect of Increase of Dry Materials Temperature on the Compressive Strength of PEG 400 Mixes}

By comparing the strength of mixes prepared using dry materials at $50{ }^{\circ} \mathrm{C}$ (Table 9 ) with those prepared using dry materials at $25{ }^{\mathrm{O}} \mathrm{C}$ (Table 8), it becomes clear that the increase of the temperature of the site stockpiles, had a detrimental effect on the compressive strength of concrete. The percentage reduction in compressive strength due to the increase in dry mix material from 25 to $50^{\circ} \mathrm{C}$ is shown in Figure 3. At 28 days, when the temperature of the dry materials was increased from $25^{\circ} \mathrm{C}$ to $50^{\circ} \mathrm{C}$, the $\mathrm{NC}$ mixes lost between $52.9-60.5 \%$ of their compressive strength. Kamal et al. [28] recorded a compressive strength of $39.5 \mathrm{MPa}$ for mixes prepared using dry materials having a temperature of $25^{\circ} \mathrm{C}$, water with a temperature of $20^{\circ} \mathrm{C}$ and water cured at a temperature of $25^{\circ} \mathrm{C}$. When Kamal et al. [28] increased the dry materials temperature to $50{ }^{\circ} \mathrm{C}$, whilst keeping all other conditions the same, the recorded compressive strength was $20 \mathrm{MPa}$ only. This $49 \%$ reduction in compressive strength shown in the mixes prepared by Kamal et al. [28] is comparable to that observed in the current investigation for NC mixes.

It was interesting to observe that the reduction in strength was comparable for all $\mathrm{NC}$ mixes, regardless of the temperature of the mixing water (which was either 5,25 or $35^{\circ} \mathrm{C}$ ), because the dry materials usually constitute more than $90 \%$ of the concrete weight. It appears that the temperature of the stockpiles is more significant than mixing water temperature.

The inclusion of the PEG 400 self-curing admixtures (i.e. SC) resulted in a loss of only 30 $38.1 \%$ when the temperature of the dry materials was increased from $25^{\circ} \mathrm{C}$ to $50{ }^{\circ} \mathrm{C}$. Again, the reduction was comparable for all SN mixes regardless of the mixing water temperature. The results of the current investigation, therefore, indicate that the increase in dry mixing materials temperatures reduced the compressive strength by an average of 55.6 or $34 \%$ for $\mathrm{NC}$ and SC mixes, respectively. Nasir et al. [49], prepared concrete mixes at 25, 32, 38 or 45 ${ }^{\mathrm{O}} \mathrm{C}$. These mixes were cured outdoors in the hot summer in Saudi Arabia by covering with wet burlap. They controlled the temperature of the concrete during casting by changing the mixing water and dry materials temperature. Nasir et al. [49] reported that the strength of the Portland cement concrete at 28 days is increased with the increase in its casting temperature up to $32{ }^{\circ} \mathrm{C}$. If the casting temperature exceeds this threshold, the strength is reduced. For samples with supplementary cementitious materials, this "threshold casting temperature" was increased to $38^{\circ} \mathrm{C}$. In the current investigation, SC mixes lost less strength when prepared using warmer dry materials. It would appear that PEG 400 probably affects the "threshold casting temperature" causing an effect similar to supplementary cementitious materials, definitely through a different mechanism. The reasons for this observation will be further 
explained in the following sections.

\subsubsection{Effect of Increase of Mixing Water Temperature on the Compressive Strength of PEG 400 Mixes}

In the current investigation, concrete mixes were prepared using mixing water temperatures of 5,20 or $35^{\mathrm{O}} \mathrm{C}$. Table 10 shows the percentage change in compressive strength due to increasing the water temperature, relative to the compressive strength when the mixing water temperature was $5^{\circ} \mathrm{C}$. It can be seen that using warmer mixing water increases the strength at the age of 7 days to varying degrees depending on the dry mixing materials temperature, curing temperature and type of mix. However, this effect was less pronounced at 28 days, when the mixing water was at $20^{\circ} \mathrm{C}$, and a reduction in compressive strength was observed when the mixing water was at $35^{\circ} \mathrm{C}$. A similar trend was reported by Naganathan and Mustapha [50] who found that warmer mixing water increases the compressive strength at the early ages, but the strength is reduced at 28 days.

Table 10 clearly shows that a significantly higher reduction in strength was observed when the dry materials temperature was hot (i.e. $50{ }^{\mathrm{O}} \mathrm{C}$ ). Madi et al. [27] found that when the dry constituents of the concrete were at mild temperatures $\left(23^{\circ} \mathrm{C}\right)$, the compressive strength is not significantly affected by the different mixing water temperatures. However, when dry constituents of the concrete were at relatively hot Temperature $\left(45^{\circ} \mathrm{C}\right)$, cooling the mix water to $\left(5^{\circ} \mathrm{C}\right)$ contributed to an increase in the 28 -day compressive strength by up to $5 \mathrm{MPa}$. This is in line with the findings of the current investigation.

In general, the inclusion of the PEG 400 self-curing admixtures, resulted in a lower compressive strength reduction in SC mixes compared to the $\mathrm{NC}$ mixes, when the mixing water temperature was increased from $5{ }^{\circ} \mathrm{C}$ to $35^{\circ} \mathrm{C}$ (see Table 10). In fact, Table 9 shows that the $\mathrm{SC}$ mixes achieved almost the same compressive strength when cured at $50^{\circ} \mathrm{C}$, regardless of the curing water temperature. The discussion above, based on previous investigations, and the results in Tables 8,9 and 10 indicate that the effect of mixing water temperature is marginal, compared to the dry materials temperature.

\subsubsection{Effect of Increase of Curing Temperature on the Compressive Strength of PEG 400 Mixes}

In this investigation the $\mathrm{NC}$ mixes were water cured at either $25^{\circ} \mathrm{C}$ or $50^{\circ} \mathrm{C}$, whereas the SC mixes were air cured at $25{ }^{\circ} \mathrm{C}$ or cured in an oven at $50{ }^{\circ} \mathrm{C}$. Table 11 shows the ratio of the compressive strength when the curing temperature was $50^{\circ} \mathrm{C}$ to that when it was $25^{\circ} \mathrm{C}$. It can be seen that at the age of 7 days, curing at $50{ }^{\circ} \mathrm{C}$ resulted in an increase in the compressive strength of both $\mathrm{NC}$ and $\mathrm{SC}$ mixes (ratio $>1$ in Table 11). The trend was reversed for the results at 28 days (ratio $<1$ in Table 11). Hameed [51], cured samples in water at room temperature or in an oven at $60{ }^{\circ} \mathrm{C}$ for 7 days and reported that the oven cured samples exhibited higher compressive strengths. Similarly, Al-Amoudi et al. [52] cured mortar samples with Portland cement or blended cements at $25,40,55$ and $70{ }^{\circ} \mathrm{C}$. They also observed that early age strength was enhanced by hot curing. Naganathan and Mustapha [50] found that the increase in curing water temperature (between 20 and $50^{\circ} \mathrm{C}$ ) leads to progressive loss in attained compressive strength at 28 days for normal mixes. Chand et al. [21] prepared normal concrete and containing PEG 4000 (a higher molecular weight curing agent) mixes and cured them either in air or water at $27^{\circ} \mathrm{C}$ or in an oven at $60{ }^{\circ} \mathrm{C}$ until testing. They reported that oven curing increased the compressive strength of the samples at the early ages compared to those air cured at room temperature, but at later ages the reverse was observed.

The SC concrete prepared with dry materials $20{ }^{\circ} \mathrm{C}$, mixing water at $35{ }^{\circ} \mathrm{C}$ and cured in the oven at $50^{\circ} \mathrm{C}$, exhibited a slightly better strength retention at 28 days $(0.88)$ compared to the 
$\mathrm{NC}$ mixes cured in warm water at $50{ }^{\circ} \mathrm{C}(0.87)$. For other, mixing water temperatures, the strength ratios of the SC mixes were slightly lower than the NC mixes. This indicates that when the curing temperature is high, PEG 400 performs marginally better when it was also combined into the mix using warmer water.

The 28 days strength ratios in Table 11, for the mixes prepared when the dry materials were hot at $50{ }^{\circ} \mathrm{C}$, indicate that the inclusion of PEG 400, lead to slightly higher strength retention ratios for SC mixes (i.e. 0.96, 0.93, 0.98) compared to $\mathrm{NC}$ mixes $(0.92,0.89 .0 .9)$, when the curing temperature was increased from $25^{\circ} \mathrm{C}$ to $50{ }^{\circ} \mathrm{C}$. This confirms that PEG 400 performs better to some extent when the initial mix temperature is hot. However, the effect of curing temperature exhibited in this investigation seem to be less important than other test variables.

Chand et al. [21] reported that the samples containing PEG 4000 cured at $60{ }^{\circ} \mathrm{C}$ exhibited a higher compressive strength at 28 days than those air cured at $27^{\circ} \mathrm{C}$, but their compressive strength was lower than those water cured at $27^{\circ} \mathrm{C}$. They explained the results by studying the weight loss of the samples cured in air and in the oven. They noted that samples with PEG 4000 retained more water, and hence better hydration was achieved. The results in Tables 8 and 9 show that the SC mixes oven cured at $50{ }^{\circ} \mathrm{C}$ exhibited higher compressive strength compared to $\mathrm{NC}$ mixes water cured at $25{ }^{\circ} \mathrm{C}$ in some cases. This is in line with the findings of Mousa et al. [17] who prepared samples with and without PEG 200 cured at moist air $(65 \%$ $\mathrm{RH}, 25^{\circ} \mathrm{C}$ ) or in an oven at $50{ }^{\circ} \mathrm{C}$. They reported that PEG 200 samples cured at $50{ }^{\circ} \mathrm{C}$ exhibited a higher compressive strength compared all the other samples. The reasons for the improved performance during elevated temperature curing will be further explored in the following sections.

\subsection{Results of the Splitting Tensile Strength Test}

The results of the splitting tensile strength for the mixes with and without the PEG 400 selfcuring agent prepared in different conditions are shown in Table 12. The values of the splitting tensile strength were affected by the different conditions in a similar manner to the compressive strength. The discussion above, related to compressive strength, indicated that studying the effect of inclusion of PEG 400 and the effect of dry materials temperature on the performance of the PEG 400 would be sufficient to evaluate the effectiveness of SN mixes in hot weather. Other variables such as mixing water temperature and curing temperature were of less importance.

\subsubsection{Effect of Inclusion of PEG 400 on the Splitting Tensile Strength of Concrete}

Table 13 shows the percentage change in the splitting tensile strength of mixes due to the inclusion of PEG 400. It should be noted that in this investigation the SC mixes were air cured, and the NC mixes were water cured. All the results show improvement in the splitting tensile strength due to the utilization of the self-curing admixture, especially when the dry materials temperature was hot at $50^{\circ} \mathrm{C}$.

It can be seen from Table 13 that the increase in splitting tensile strength due to the inclusion of PEG 400 for samples prepared in laboratory conditions was $10.8 \%$. Mousa et al. [43] studied mixes with and without polyethylene-glycol, prepared and cured in laboratory air at 25 ${ }^{\mathrm{O}} \mathrm{C}$. They reported that the samples with $2 \%$ self-curing agent exhibited $14.8 \%$ increase in splitting tensile at 28 days compared to the samples without this admixture. In their study the inclusion of the self-curing agent had a more pronounced effect on the splitting tensile strength, probably because their normal concrete mixes were air cured, not water cured as in the current investigation. Therefore, the effect of PEG 400 was more pronounced in their study compared to the current investigation. Similarly, Kumar et al. [53] prepared mixes with and without $0.5 \%$ PEG 400. Their mixes were $w / c=0.42$ and grade M40, which are similar to the mixes in the 
current investigations. They reported that the inclusion of PEG 400 increased the splitting tensile strength by $13 \%$. Again, their normal concrete samples were also air cured, not water cured as in the current investigation. Therefore, the results of the current investigation are comparable to previous work for the mixes prepared in laboratory conditions.

Goel et al. [54] investigated the effect of curing regimes on the splitting tensile strength of concrete. They reported that at 28 days, samples cured in laboratory air achieved $36.7 \%$ less splitting tensile strength compared to water cured counterparts. The results of the current investigation indicate that PEG 400, overcomes the expected reduction due to the absence of moist curing, and further enhances the splitting tensile strength compared to that obtained in standard curing conditions.

Table 13 shows that the performance of PEG 400 was better in the samples which were prepared when the dry materials temperature was $50^{\circ} \mathrm{C}$, compared to those prepared at $25^{\circ} \mathrm{C}$. The authors could not cite any studies conducted on the mechanical properties of self-curing concrete prepared at warm temperatures during casting for comparison. Reasons for this observation shall be further explored.

\subsubsection{Effect of Increase of Dry Materials Temperature on the Splitting Tensile Strength of PEG 400 Mixes}

In Table 14, the effect of increase in dry materials temperature during mixes on the tensile strength of the mixes is shown. It can be seen that the tensile strength was reduced to different degrees at higher temperatures. However, the reduction was less for SC mixes compared to NC mixes as observed in section 4.2.2 above for compressive strength. The percentage reduction in the compressive strength due to the increase in dry materials temperature was more than that observed for the splitting tensile strength. A similar effect was noted by Deghfel et al. [55] for typical roller compacted concrete in hot climates.

Kamal et al. [28] recorded a splitting tensile strength of $3.57 \mathrm{MPa}$ for mixes prepared using dry materials having a temperature of $25^{\circ} \mathrm{C}$, mixing water at temperature of $20^{\circ} \mathrm{C}$ and water cured at a temperature of $25^{\circ} \mathrm{C}$. When Kamal et al. [28] increased the dry materials temperature to $50{ }^{\circ} \mathrm{C}$, whilst keeping all other conditions the same, the recorded splitting tensile strength was $2.86 \mathrm{MPa}$ only. This is almost $20 \%$ reduction in splitting tensile strength and is comparable to the reduction for $\mathrm{NC}$ in similar conditions shown in Table 14 (reduction of 21.6 for NC mixes prepared in similar conditions).

\subsection{Results of the Flexural Strength Test}

The results of the flexure strength of the specimens are shown in Table 15. It can be seen that the flexural strength was improved the inclusion of the self-curing admixture. Mousa et al. [43] found that the flexural strength was increased by 2 and $6.8 \%$ when 1 or $2 \%$ of PEG 200 was added to mixes prepared in standard conditions, respectively. In the current investigation, with $1.5 \%$ PEG, this percentage was $3.7 \%$ for the mix prepared under similar conditions, whereas this percentage was $8 \%$, when the dry materials temperature was $50^{\circ} \mathrm{C}$. Again, PEG 400 inclusion seems to enhance the mechanical properties when the fresh mix temperature is warm.

It can also be seen from Table 15 changing dry materials, mixing water and curing water temperatures affected the values of the flexural strength to varying degrees. Madi et al [27] conducted an experimental study on the effect of mixing water temperature on the mechanical properties of normal concrete. Their samples were cured in the laboratory, and they only conducted limited tests on mixes with heated dry materials. In general, their results did not show a consistent pattern due to changing the mixing water temperature. For comparison, their 
data showed that heating the dry materials to $45^{\circ} \mathrm{C}$, resulted in a reduction of $3.5 \%$ in flexural strength when the mixing water was at $45^{\circ} \mathrm{C}$. In the current investigation, using mixing water at $35^{\circ} \mathrm{C}$, increasing in dry materials temperature from 25 to $50{ }^{\circ} \mathrm{C}$, resulted in 9.4 and $4.2 \%$ reduction in flexural strength for normal concrete samples water cured at 25 and $50{ }^{\circ} \mathrm{C}$, respectively. Madi et al. [27] mixes had $350 \mathrm{~kg} / \mathrm{m}^{3}$ cement and they employed mixing water temperature at $45^{\circ} \mathrm{C}$, whereas in the current investigation the cement content was $450 \mathrm{~kg} / \mathrm{m}^{3}$ and the mixing water was heated to $35^{\circ} \mathrm{C}$. This could explain the difference in the effect of increasing the temperature of the dry ingredients on the flexural strength.

The authors could not cite any data on the flexural strength of self-curing mixes prepared and/or cured at warm conditions for comparison. However, the results indicate that PEG 400 had a positive effect on flexural strength in hot weather conditions.

\section{ACTION OF PEG 400 IN HOT WEATHER CONDITIONS}

In this investigation, and in the published literature, PEG 400 exhibited improved performance especially at higher temperature conditions. In the next sections, the authors will attempt to explore possible reasons for this behavior.

\subsection{Microstructure of PEG Samples Cured at Various Temperatures}

Nair and Thachil [56] studied Scanning Electron Microscope (SEM) images of samples with PEG and found that the microstructure of cement composites with PEG was more homogeneous, with fewer microcracks and voids. They argued that PEG acts as a rheological additive and forms a film around the cement matrix.

El-Dieb et al. [57] observed that Portlandite crystals do not have obvious edges or corners in samples with PEG 6000 and argued that the dense microstructure of samples with PEG 6000 did not allow Portlandite crystals to grow. Chand et al. [23] examined the microstructure of samples with and without PEG 200 and PEG 4000 self-curing agents. Their mortar samples were subject to one of three curing conditions (no curing, curing by conventional water immersion and self/internal curing). The no cured mortar sample exhibited micro cracks, amorphous and poor crystalline form of calcium silicate hydrate and more quantities of calcium hydroxide plates. The water cured samples had a strong crystalline form of calcium silicate hydrate gel, hexagonal plates of calcium hydroxide (Portlandite), fewer pores and no micro cracks. They argued that the heat liberated during the hydration process in no cured samples, caused self-desiccation and micro cracks giving a porous and pervious mortar structure. Conversely, the microstructure images of the self-compacting mortars revealed the presence of dense fibrous $\mathrm{C}-\mathrm{S}-\mathrm{H}$ and minimum voids. They attributed this to the action of the self-curing admixtures, which blocked the pores preventing the movement of water vapour to the surface. This water promoted further hydration to form dense $\mathrm{C}-\mathrm{S}-\mathrm{H}$, small amounts of Portlandite and minimized the volume of pores.

Chand et al. [29] prepared Grade 70 concrete samples with and without PEG 4000 self-curing admixture. They cured conventional samples in water or air at ambient temperature $\left(27^{\circ} \mathrm{C}\right)$ or at elevated temperature $\left(50^{\circ} \mathrm{C}\right)$, whereas the samples with PEG 4000 were air cured in the two temperatures. Their XRD analysis results show that the Portlandite phase in samples with PEG 4000 was $8.1 \%$ and $10.1 \%$ for samples cured at $\left(27^{\circ} \mathrm{C}\right)$ and $\left(50^{\circ} \mathrm{C}\right)$, respectively. Both values were slightly lower than the amount formed in water cured conventional samples $(11 \%)$. Samples without PEG 4000 had $18 \%$ and $23.8 \%$ when cured at $\left(27^{\circ} \mathrm{C}\right)$ and $\left(50^{\circ} \mathrm{C}\right)$, respectively. Therefore, the amount of Portlandite formed in samples with PEG 4000 was less than half that in air cured plain samples at both temperatures. In addition, air cured samples without PEG, exhibited interlinking of microcracks and pores in the ITZ, Portlandite crystals 
and a minimum quantity of $\mathrm{C}-\mathrm{S}-\mathrm{H}$ phases when cured at $50^{\circ} \mathrm{C}$ in contrast to $\mathrm{PEG} 4000$ samples which exhibited a denser microstructure at the high temperature curing.

In the authors view, the prevention of escape of water form samples containing PEG does not fully explain the presence of a smaller amount of Portlandite crystals, the appearance of Portlandite crystals without edges, or the formation of a dense microstructure in PEG samples even at high temperature curing.

\subsection{Solubility of $\mathrm{Ca}(\mathrm{OH})_{2}$ in PEG 400 Solutions}

In dentistry, Calcium Hydroxide $\left(\mathrm{Ca}(\mathrm{OH})_{2}\right)$ pastes have been used in endodontics in root canal treatments since 1947 . Traditionally the pastes were water based, however, Wright and Walsh [58] and Athanassiadis \& Walsh [59] found that the solubility of $\mathrm{Ca}(\mathrm{OH})_{2}$ is improved in the presence of Polyethylene Glycol (PEG 400) giving better results in treatments. By analogy, it would be safe to conclude that less Portlandite is deposited concrete samples with PEG 400, probably due to the increased solubility of $\mathrm{Ca}(\mathrm{OH})_{2}$ in the presence of PEG 400. In addition, the increased solubility of $\mathrm{Ca}(\mathrm{OH})_{2}$ would also explain why some of the corners of the Portlandite crystals that do form are prone to attrition and appear with no corners in SEM images. In conventional concrete, Portlandite $\mathrm{Ca}(\mathrm{OH})_{2}$ crystals are usually deposited in the Interfacial Transition Zone (ITZ) in concrete making this area the weakest link in concrete. Indeed, when subjecting concrete to loads the fracture paths usually occur in ITZ [60]. With less Portlandite, the ITZ is strengthened in PEG composites and hence the mechanical properties are improved.

\subsection{Hydration Reaction of Cement in the Presence of PEG 400}

Shortly after mixing the cement with water $\mathrm{C}_{3} \mathrm{~S}$ starts to react in accordance with the reaction:

$\mathrm{C}_{3} \mathrm{~S}+3.9 \mathrm{H} \rightarrow \mathrm{C}_{1.7} \mathrm{SH}_{2.6}+1.3 \mathrm{CH}$

This reaction is exothermic and is accelerated when the mix temperature is increased, leading to rapid availability of $\mathrm{Ca}(\mathrm{OH})_{2}$ in solution [61]. The reaction slows down during the dormant period until $\mathrm{Ca}(\mathrm{OH})_{2}$ and C-S-H start to precipitate [62]. However, as mentioned above the solubility of $\mathrm{Ca}(\mathrm{OH})_{2}$ is increased with the addition of PEG 400. Bye et al. [63] found that in saturated $\mathrm{Ca}(\mathrm{OH})_{2}$ solutions, when $\mathrm{Ca}(\mathrm{OH})_{2}$ is prevented from precipitating, a significant lengthening of the dormant period is observed. Bilek et al. [64] found that PEG pastes produce less heat of hydration. Hameed et al. [65] and Radwan et al. [66] reported increased setting times for samples with PEG 400, which indicates slowing down of hydration reactions. Therefore, in the presence of PEG 400, hydration is retarded by prolonging the dormant period and hence reducing the evolved heat of hydration. This would allow for the formation of a dense homogeneous microstructure as seen in SEM images, even in hot weather conditions.

\subsection{Effect of PEG 400 on the Structure of Hydration Products}

Mikhailova and Rovnaník [67] found that the inclusion of PEG 400 leads to the domination of small sized pores in the hydration matrix. Zhou et al. [68] found that PEG 400 modifies the meso-structure of C-S-H. They found that PEG polymers become intercalated, hence filling the defects of the silicate chains, thereby increasing the system connectivity and improving the ductility of C-S-H, which in turn, produces the positive effect on the mechanical properties. They proposed a model in which PEG molecules are positioned between the C-S$\mathrm{H}$ products, parallel to the neighboring calcium silicate sheets forming bonds with sheets on opposite sides. Their model is shown in Figure 4. This arrangement leads to reduction in 
pore space, strengthening of the hydration products and contributes to the observed improvement in mechanical properties.

\subsection{Effect Temperature on the Viscosity of PEG 400}

Although PEG 400 is completely soluble at $20^{\circ} \mathrm{C}$. During studying the physical properties of PEG 400 for pharmaceutical applications, Padmanaban et al. [69] found that its' relative viscosity is decreased with the increase in temperature. Their study covered the temperature range of $303-318{ }^{\circ} \mathrm{K}$, which is approximately $30-45^{\circ} \mathrm{C}$. It can be argued that due to the reduction of viscosity of PEG 400 at higher temperatures, this admixture is dispersed in a more efficient manner when the temperature of the fresh concrete is high (i.e. dry mixing materials are hot). Therefore PEG 400 is able to contribute more effectively to the above-mentioned processes in hot weather conditions as seen in the results of the current investigation.

\section{CONCLUSIONS}

There is limited published data on the performance of admixtures such as PEG 400 self-curing agent in hot weather conditions. In this research, a series of experiments were conducted to investigate the behaviour of self curing concrete (SC) with PEG 400, cast and cured in hot climate conditions, in comparison with conventional normal concrete (NC). Based on the experimental results presented, the following conclusions can be drawn:

1. The inclusion of PEG 400 in concrete resulted in an increase in the workability of the fresh concrete along with the compressive, tensile and fleuxural strengths in comparison with mixes without this admixture under all conditions.

2. The mechnical properties for the concrete made with dry materials mixed at $50^{\circ} \mathrm{C}$ were inferior to those when the dry materials were mixed at $25^{\circ} \mathrm{C}$. However, samples with PEG 400 were less affeted by the increase in the dry materials temperature.

3. Increasing the dry materials temperature from 25 to $50{ }^{\circ} \mathrm{C}$ had a more profound effect on the mechnical properties of tested concrete, compared to changes to mixing water temperture $\left(5,20,35^{\circ} \mathrm{C}\right)$, or curing water temperature $\left(25\right.$ or $\left.50^{\circ} \mathrm{C}\right)$.

4. The improved performance of the PEG 400 samples especially at hot conditions, as seen in the current investigation cannot be simply attributed to water retention in PEG 400 samples leading to better hydration.

5. The authors postulate that PEG 400 performs better in hot conditions as a result of the reduced viscosity of this material at higher temperatures, the retarding effect of PEG 400, and the induced increase in solubility of $\mathrm{Ca}(\mathrm{OH})_{2}$, leading to improvement in ITZ. In addition, PEG 400 chains become positioned in between the C-S-H sheets leading to refining of the pores in cement hydration products. All of these actions counteract the adverse effects of hot weather on the concrete's internal structure.

6. PEG 400 self-curing admixture overcomes all the difficulties associated with concrete production in hot weather. Therfore, it is recommended for use in concrete in these conditions.

\section{REFERENCES}

[1] CIRIA/Concrete Society, March (2002) "Guide to the construction of reinforced concrete in the Arabian Peninsula", (C577), M Walker (ed), ISBN: 978-0-946691-93-7, 208pp. http://www.adv-technovation.com/CIRIA-bookshop/book-pages/c577

[2] Concrete Society (2005) "The role of water in concrete and its influence on properties", 
CS156. https://www.concretebookshop.com/the-role-of-water-in-concrete-and-its-influenceon-properties-1596-p.asp

[3] Al-Amoudi, O.S.B, Maslehuddin, M., Shameem, M., and Ibrahim, M. (2007) "Shrinkage of Plain and Silica Fume Cement Concrete Under Hot Weather," Cement and Concrete $\begin{array}{llllll}\text { Composites, } & \text { vol. } 29, \quad \text { no. }\end{array}$ https://doi.org/10.1016/j.cemconcomp.2007.05.006

[4] Concrete Society (2008) "PUB CS163 Guide to the design of concrete structures in the Arabian Peninsula". https://www.thenbs.com/PublicationIndex/documents/details?Pub=CS\&DocID $=325057$

[5] Almusallam, A. A. (2001). "Effect of Environmental Conditions on the Properties of Fresh and Hardened Concrete", Cement and Concrete Composites, Vol. 23(4-5), pp. 353-361. DOI: 10.1016/S0958-9465(01)00007-5

[6] Kim, J., Han, S.H., Song, Y.C. (2002). "Effect of temperature and aging on the mechanical properties of concrete Part I. Experimental results", Cement and Concrete Research, Vol. 32, pp. 1087-1094. https://doi.org/10.1016/S0008-8846(02)00744-5

[7] Wang, Q. Feng, J. J., Yan, P.Y., (2011) "An explanation for the negative effect of elevated temperature at early ages on the late-age strength of concrete". Journal of Materials Science, Vol. 46, pp. 7279-7288. https://doi.org/10.1007/ s10853-011-5689-z 28.

[8] Zacak, M., Garrault, S., Korb, J-P. , Nonat, A. (2007) "Effect of temperature on the development of C-S-H during early hydration of $\mathrm{C}_{3} \mathrm{~S}$ ". In: 12th International congress on the chemistry of cement, July 2007, Montreal, Canada, pp W1-06.2. hal-00452150 https://hal.archives-ouvertes.fr/hal-00452150

[9] ELkhadiri, I., Palacios, M., and Puertas, F. (2009). "Effect of curing temperature on cement hydration. Ceramics Silikaty, vol. 53, pp. 65-75. https://www.researchgate.net/publication/283863720_Effect_of_curing_temperature on_cem ent hydration/citations

[10] ACI 305.1-06 (2007) "Specification for Hot Weather Concreting", Reported by ACI Committee 305, American Concrete Institute 38800 Country Club Drive Farmington Hills, MI $48331 \quad$ U.S.A, www.concrete.org, ISBN 978-0-87031-242-7. http://www.arquitectosrp.com/archivo/download/ACI\%20305.106\%20Specification $\% 20$ for $\% 20$ Hot $\% 20$ Weather $\% 20$ Cncreting.pdf

[11] BS 8110-1: (1997) Structural use of concrete, "Part 1: Code of practice for design and construction", C BSI 06-1999, Second edition March 1997, ISBN 0580262081. https://www.academia.edu/4768723/Structural_use_of_concrete_Part_1_Code_of practice f or_design_and_construction

[12] ASTM C94 / C94M - 19a "Standard Specification for Ready Mixed Concrete", Michigan Concrete Association. https://www.astm.org/Standards/C94

[13] AASHTO M-157 (2013). "Standard Specification for Ready-Mixed Concrete", https://global.ihs.com/doc detail.cfm?document name=AASHTO $\% 20 \mathrm{M} \% 20157 \&$ item s k $\underline{\text { ey }=00487390}$

[14] Dhir, R. K., Hewlett, P. C., and Dyer, T. (1995) "Durability of Self-cured Concrete," Cement and Concrete Research, vol. 25, no. 6, pp. 1153-1158. https://doi.org/10.1016/0008$\underline{8846(95) 00107-\mathrm{N}}$

[15] El-Dieb, A. (2007) "Self-curing Concrete: Water Retention, Hydration and Moisture 
Transport," Construction and Building Materials, vol. 21, pp. 1282-1287. https://doi.org/10.1016/j.conbuildmat.2006.02.007

[16] ACI 308R-01 (2001) "Guide to Curing Concrete," Farmington Hills, Amarican Concrete Instituate, ACI, Detroit, USA. http://dl.mycivil.ir/dozanani/ACI/ACI\%20308R01\%20R08\%20Guide\%20to\%20Curing\%20Concrete MyCivil.ir.pdf

[17] Mousa, M.I., Mahdy, M.G., Abdel-Reheema, A.H., and Yehia, A.Z. (2015a). "Self-curing concrete types; water retention and durability", Alexandria Engineering Journal, http://dx.doi.org/10.1016/j.aej.2015.03.027

[18] Han, B., Zhang, L. and Ou, J. (2017), Chapter 4: Self-Curing Concrete. In Smart and Multifunctional Concrete Toward Sustainable Infrastructures, Springer Nature Singapore Pte Ltd. 2017, DOI 10.1007/978-981-10-4349-9

[19] Bílek, V., Mosler, T., Keršner, K., Schmid P., Dhir, R. K., Hewlett, P. C. and Csetenyi, L. J. (2002), THE POSSIBILITY OF SELF-CURING CONCRETE in Innovations and Developments In Concrete Materials And Construction. January 2002, pp. 51-60

[20] Vanisri, G. (2016). STRENGTH CHARACTERISTICS OF SELF-CURING CONCRETE USING POLYETHYLENE GLYCOL (PEG), International Journal in IT and Engineering, Vol. 4, No. 2, pp. 1-7, available at https://www.indianjournals.com/ijor.aspx?target $=$ ijor:ijie $\&$ volume $=4 \&$ issue $=2 \&$ article $=001$

[21] Chand, M. S. R., Shaik, K. S., Velivela, R., Karri, V. K. (2020). "Hydrophilic and hydrophobic chemicals as self curing agents in self compacting concrete", Journal of Building Engineering, Vol. 25, March 2020, 101008. https://doi.org/10.1016/j.jobe.2019.101008

[22] Choubey, U. B., and Raghuvanshi, G., (2017). "A STUDY ON PROPERTIES OF SELFCURING CONCRETE USING POLYETHYLENE GLYCOL-400”, International Research Journal of Engineering and Technology (IRJET) e-ISSN: 2395-0056 Volume: 04 Issue: 10, Available at https://www.academia.edu/35115595/_A STUDY ON_PROPERTIES OF SELF-CURING CONCRETE USING POLYETHYLENE GLYCOL-400

[23] Chand, M. S. R., Giri, P. S. N. R. , Kumar, P. R. , Kumar, G. R. and Raveena, C. (2016). "Effect of self-curing chemicals in self-compacting mortars". Construction and Building Materials, 107, 356-364. http://dx.doi.org/10.1016/j.conbuildmat.2016.01.018

[24] Bashandy, A., A., Meleka, and Hamad, M. M. (2017) "Comparative Study on the Using of PEG and PAM as Curing Agents for Self-Curing Concrete," Challenge Journal of Concrete Research Letters, vol. 8, no. 1, pp. 1-10. DOI: https://doi.org/10.20528/cjcrl.2017.01.001

[25] Assal, M. A., 2017, "Effect of Mixing Water Temperature on Concrete Properties in Hot Weather Conditions", MSc Thesis, the American University in Cairo, 104 pp. http://dar.aucegypt.edu/bitstream/handle/10526/5285/The $\% 20$ Effect $\% 20$ of $\% 20$ Mixing $\% 20$ Water $\% 20$ Temperature $\% 20$ on $\% 20$ Concrete $\% 20$ Properties $\% 20 \mathrm{in} \% 20 \mathrm{Hot} \% 20$ Weather $\% 20 \mathrm{C}$ onditions $\% 20-\% 20$ Mennatallah $\% 20$ Assal.pdf?sequence $=1$

[26] Negm El Din, A.; Ziada, F.; Madi, M.; Mazen, M.; Refaat, N.; Ahmed, S.; Hamza, A.; El Nahas, E.; Fathy, A.; Fahmy, E. \& Abou-Zeid, M. (2017) Impact of Mixing Water Temperature on Portland Cement Concrete Performance. 2017 CSCE Annual Conference, Vancouver, British Columbia, Canada, May 31 - June 3, 2017. http://uhpc.com.vn/wpcontent/uploads/2018/10/CSCE-2017-BookOfAbstracts-Copy.pdf

[27] Madi, M.; Refaat, N.; Negm El Din, A.; Ziada, F.; Mazen, M.; Ahmed, S.; Hamza, A.; Nahas, E.; Fathy, A.; Fahmy, E. \& Abou-Zeid, M. (2017) Impact of Mixing Water Temperature on Portland Cement Concrete Quality. 2017 CSCE Annual Conference, Vancouver, British 
$\begin{array}{lllllll}\text { Columbia, } & \text { Canada, } & \text { May } & 31 & - & \text { June } & 3,\end{array}$ https://www.researchgate.net/publication/318116822 THE IMPACT OF MIXING WATE R TEMPERATURE_ON_PORTLAND_CEMENT_CONCRETE_QUALITY

[28] Kamal, M.M., Etman, Z.A., Bashandy, A.A., Nagy, M. (2019) “ Behavior improvement of self-compacting concrete in hot weather", Challenge Journal of Concrete Research Letters, Vol 10, No. 4, pp. 89-104. https://doi.org/10.20528/cjcrl.2019.04.003

[29] Chand, M. S. R., Kumar, P. R., Giri, P. S. N. R., and Kumar, G. R (2018). "Performance and microstructure characteristics of self-curing self-compacting concrete", Advances in Cement Research, vol. 30, No10, pp. 451-468. https://doi.org/10.1680/jadcr.17.00154

[30] Al-Martini, S. and Nehdi, M., (2007). "Effect of chemical admixtures on rheology of cement paste at high temperature," Journal of ASTM International, vol. 4, No. 3., Paper ID JAI100554

pp.

$11-17$.

https://www.researchgate.net/profile/Moncef_Nehdi/publication/289909134

Effect of chemcal admixtures and high temperatues on yield stress and plastic viscosi ty of cementpastes/links/589750d14585158bf6f59852/Effect-of-chemcal-admixtures-andhigh-temperatues-on-yield-stress-and-plastic-viscosity-of-cement-pastes.pdf

[31] ES 4756-1: (2009) Cement Part:( 1) Composition, Specifications And Conformity Criteria For Common Cements, Egyptian Organization for Standardization and Quality (EOS)

[32] ASTM.C-33 (2003) "Aggregates," American Society for Testing and Materials ASTM International, Philadelphia, USA. https://www.astm.org/Standards/C33

[33] Anon (2020), Polyethylene glycol, https://en.wikipedia.org/wiki/Polyethylene_glycol

[34] BS 8500-1: (2015) Concrete, "Method of specifying and guidance for the specifier", Complementary British Standard to BS EN 206. https://shop.bsigroup.com/ProductDetail?pid=000000000030371362

[35] BS EN 12350-2: (2019) “Testing fresh concrete. Slump test”, BSI, ISBN: 9780580 984297. https://shop.bsigroup.com/ProductDetail/?pid=000000000030360058

[36] ASTM C348 - 19, Standard Test Method for Flexural Strength of Hydraulic-Cement Mortars, Active Standard ASTM C348, Developed by Subcommittee: C01.27, ASTM International, West Conshohocken, PA, 2019, www.astm.org

[37] Kushwaha, A. and Parihar, S. (2018). "Self-Curing by using of Super Absorbent Polymer and Shrinkage Reducing Admixture for M-40", IJSTE - International Journal of Science Technology \& Engineering | Volume 4 | Issue 11 | May 2018, http://www.ijste.org/articles/IJSTEV4I11054.pdf

[38] Kumar, M. V. J., Srikanth, M. and Rao, K. J., (2012), STRENGTH CHARACTERISTICS OF SELF-CURING CONCRETE”, IJRET, pp. 51- 57. https://pdfs.semanticscholar.org/baee/159d0f3fb89ed9c6e55212e909338f3d8086.pdf

[39] Tyagi, S. (2015), “Comparison of Strength Characteristics of Self Cured Concrete”, International Research Journal of Engineering and Technology (IRJET), Vol. 2, No.6, 133135.https://www.academia.edu/16392893/IRJET-Comparison_of_Strength_Characteristics of Self Cured Concrete

[40] Prakash, T. and Venkatesh, P. (2016) "Experimental studies on the Properties of SelfCuring Concrete Using Polyethelene Glycol", International Jounal of Modern Trends in Engineering and Science, Vol. 3, No. 7, pp. 193- 196, http://ijmtes.com/wpcontent/uploads/2016/05/IJMTES030746.pdf 
[41] Knapen, E., Van Gemert, D. (2009). "Cement hydration and microstructure formation in the presence of water soluble polymers" . Cement and Concrete Research, Vol. 39, pp. 613. doi:10.1016/j.cemconres.2008.10.003

[42] Ahmed, H. K, Khalil, W. I., and Jumaa, N. H. (2018). "Effect of Impact Hot- Dry Weather Conditions on the Properties of High Performance Lightweight Concrete", Engineering and Technology Journal, Vol. 36, Part A, No. 3, pp.262-273. Retrieved from http://engtechjournal.org/index.php/et/article/view/160

[43] Mousa, M.I., Mahdy, M.G., Abdel-Reheema, A.H., and Yehia, A.Z. (2015)b. Mechanical properties of self-curing concrete (SCUC), HBRC Journal, 11:3, 311-320, DOI: $\underline{10.1016 / \text { i.hbrcj.2014.06.004 }}$

[44] Vaisakh G., Kumar, M. S. R., Bala, P. S. (2018). AN EXPERIMENTAL STUDY ON PROPERTIES OF M50 CONCRETE CURED USING PEG 400. International Journal of Civil Engineering and Technology (IJCIET) Volume 9, Issue 5, May 2018, pp. 725-732, Article ID: IJCIET_09_05_080 Available online at http://www.iaeme.com/ijciet/issues.asp?JType=IJCIET\&VType=9\&IType=5

[45] Dhir R. K., Hewlett P. C., Lota J. S., Dyer T. D. (1994). "An investigation into the feasibility of formulating 'self-cure' concrete". Materials and Structures, 27(10), pp. 606615. https://doi.org/10.1007/BF02473130

[46] Bentz, D. P., Lura, P., and Roberts, J. W. (2005) "Mixture Proportioning for Internal Curing," Concrete International, vol. 27, no. 2, pp. 35-40. https://www.researchgate.net/publication/234155043 Mixture Proportioning for_Internal_C uring

[47] Bentz, D. P. (2006) "Influence of Shrinkage Reducing Admixtures on Early-Age Properties of Cement Pastes," Journal of Advanced Concrete Technology, vol. 4, no. 3, pp. 423-429. DOI: $10.3151 /$ jact.4.423

[48] Mousa, M.I., Mahdy, M.G., Abdel-Reheema, A.H., and Yehia, A.Z. (2015)c. Physical properties of self-curing concrete (SCUC). HBRC Journal, 11:2, 167-175, DOI: $\underline{10.1016 / \text { j.hbrcj.2014.05.001 }}$

[49] Nasir, M., Al-Amoudi, O.S.B., Al-Gahtani, H.J. and Maslehuddin, M. (2016), "Effect of casting temperature on strength and density of plain and blended cement concretes prepared and cured under hot weather conditions", Construction and Building Materials, Vol. 112, pp. 529-537. DOI: 10.1016/j.conbuildmat.2016.02.211

[50] Naganathan, S., \& Mustapha, K.N. (2015). Effect of water temperature on concrete properties Jordan Journal of Civil Engineering, Volume 9, No. 3, DOI:10.14525/jjce.9.3.3072

[51] Hameed, A.H. (2009). "The Effect of Curing Condition on Compressive Strength in High Strength Concrete." Diyala Journal of Engineering Sciences,2(1), 35-48.

[52] Al-Amoudi, O.S.B, Almusallam, A. A., Khan, M. M. and Maslehuddin, M. (1995), Effect of Hot Weather on the compressive Strength of Plain and Blended Cement Mortars. The Fourth Saudi Engineering Conference, November 1991, Volume II, pp. 193-199.

[53] Kumar, M. V. J., Rao, K. J., Kumar, B. D., and Reddy, V. S. (2018). Effect of polyethylene glycol on the properties of self-curing concrete. International Journal of Engineering \& Technology, 7(3.29), 529-532. doi: http://dx.doi.org/10.14419/ijet.v7i3.29.19305

[54] Goel, A., Narwal, J., Verma, V., Sharma, D. and Singh, B. (2013). A Comparative Study on the Effect of Curing on the Strength of Concrete. International Journal of Engineering and 
Advanced Technology. Vol. 2, Issue-6, August 2013, http://citeseerx.ist.psu.edu/viewdoc/download?doi=10.1.1.676.241\&rep=rep1\&type=pdf

[55] Deghfel, M., Meddah, A., Beddar, M. and Chikouche, M. A. (2019). "Experimental study on the effect of hot climate on the performance of roller-compacted concrete pavement", Innovative Infrastructure Solutions, Vol. 4, Article 54. https://doi.org/10.1007/s41062-019$\underline{0246-8}$

[56] Nair, P. S. and Thachil, E. T. (2010), Microstructural Studies of Cement Composites of Thermoplastics, Polymers and Polymer Composites, Volume: 18 issue: 2, page(s): 75-83 https://doi.org/10.1177\%2F096739111001800203

[57] El-Dieb, A. S., El-Maaddawy, T. A., and Mahmoud, A. A. (2012). "Water-soluble polymers as self-curing compounds in cement mixes". Advances in Cement Research. Vol. 24, No.5, pp. 291-299, https://www.icevirtuallibrary.com/doi/10.1680/adcr.11.00030

[58] Wright, P. P and Walsh, L. J. (2017), Optimising Antimicrobial Agents in Endodontics, In Antibacterial Agents, Ed. Kumavath, R. (2017)., Rijeka : InTech publisher. https://www.intechopen.com/books/antibacterial-agents/optimizing-antimicrobial-agents-inendodontics. DOI: $10.5772 / 67711$

[59] Athanassiadis, B. \& Walsh, L. J (2017). Aspects of Solvent Chemistry for Calcium Hydroxide Medicaments, Materials, Vol. 10, http://www.mdpi.com/journal/materials. doi.org/10.3390/ma10101219

[60] Mindess, S. (1996), "Tests to Determine the Mechanical Properties of the Interfacial Zone". Chapter 3 in Interfacial transition zone in concrete, State-of-the-Art Report prepared by RILEM TC 108-ICC, edited by Maso, J. C. (E \& FN Spon, London, 1996)

[61] Hesse, C. , Goetz-Neunhoeffer, F., Neubauer, J., Braeu, M., and Gaeberlein, P. (2009) Quantitative in situ X-ray diffraction analysis of early hydration of Portland cement at defined temperatures. Powder Diffraction, Vol. 24, pp. 112-115. DOI: https://doi.org/10.1154/1.3120603

[62] Artioli, G. and Bullard, J.W. (2013). Cement hydration: The role of adsorption and crystal growth. Crystal Research Technology, Vol. 48, pp. 903-918. DOI: 10.1002/crat.201200713

[63] Bye, G., Livesey, P. and Struble, L. (2011). The hydration of Portland Cement. ICE Publishing. doi: 10.1680/pc.36116.089

[64] Bílek, V., Kalina, L., Novotný, R. (2018). "Polyethylene glycol molecular weight as an important parameter affecting drying shrinkage and hydration of alkali-activated slag mortars and pastes." Construction and Building Materials. Vol. 166, pp 564-71. https://doi.org/10.1016/j.conbuildmat.2018.01.176

[65] Hameed, A. M., Rawdhan, R. R. and. Al- Mishhadani, S. A. (2017). "Effect of self-curing agents on the different properties of cement and mortar", International Journal of Current Research, vol. 9, No. 7, pp. 54586-54594. ISSN: 0975-833X

[66] Rawdhan, R.R., Hameed, A.M., and Salih, Sh. A. (2018). "Using Polyethylene Glycol to Produce Self Cured Cement Mortar," Engineering and Technology Journal, Vol. 36, Part A, No. 4, pp. 104-408. DOI: http://dx.doi.org/10.30684/etj.36.4A.6

[67] Mikhailova, O. and Rovnaník, P. (2016). "Effect of polyethylene glycol addition on metakaolin-based geopolymer", Procedia Engineering, Vol. 151, pp. 222 - 228, doi: $\underline{10.1016 / \text { j.proeng.2016.07.379 }}$ 
[68] Zhou, Y., Orozco, C.A., Duque-Redondo, E., Manzano, H., Geng, G., Feng, P., Monteiro, P.J.M., Miao, C. (2019). "Modification of poly(ethylene glycol) on the microstructure and mechanical properties of calcium silicate hydrates", Cement and Concrete Research, Vol. 115, Pages 20-30, https://doi.org/10.1016/j.cemconres.2018.10.001

[69] Padmanaban, R., Venkatramanan, K., Girivel, S., Kasthuri, K., Usharani, A. and Vellaichamy, R. (2017), "Thermal and Rheological Studies of Aqueous Solutions of PEG 400 and PEG 1500 Having Pharmaceutical Applications", Recent Trends in Materials Science and Applications, Springer Proceedings in Physics 189, J. Ebenezar (ed.), Springer International Publishing Switzerland, pp. 723-730. DOI 10.1007/978-3-319-44890-9 58 


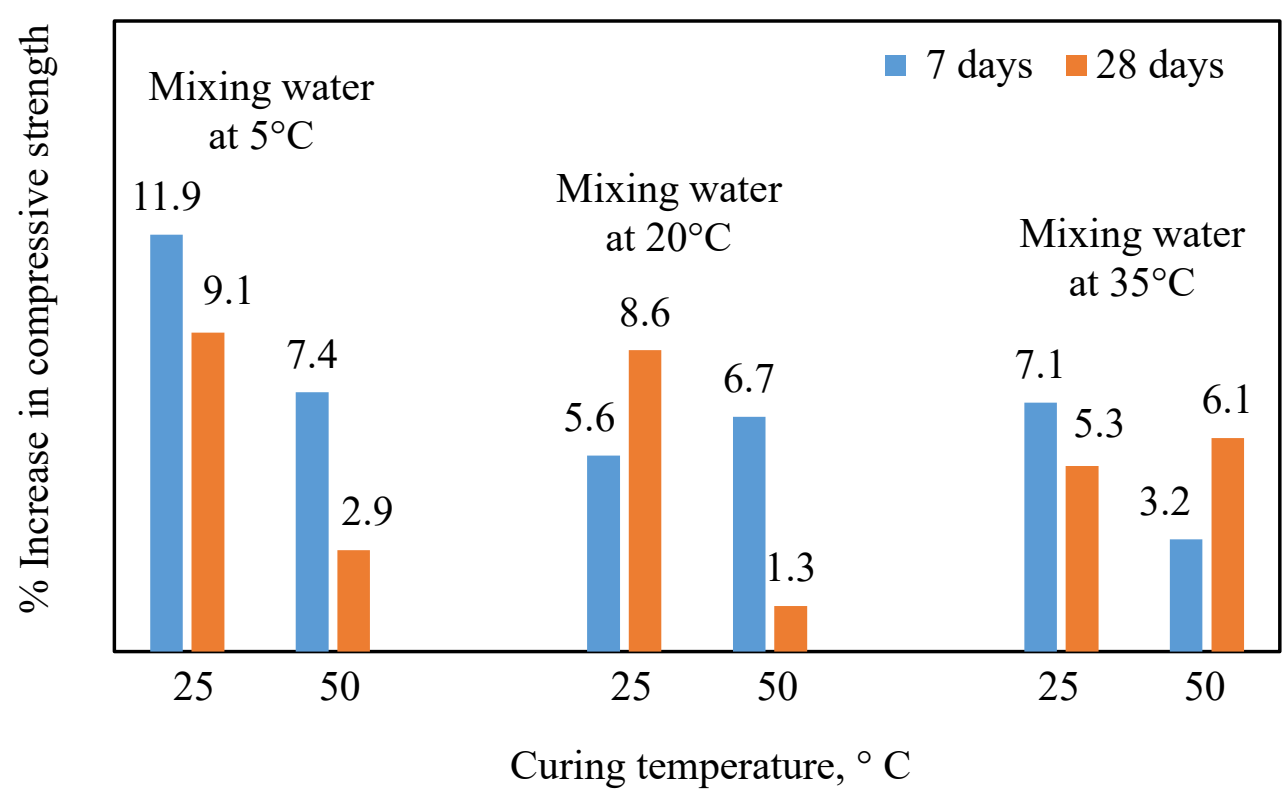

Figure 1 Percentage increase in compressive strength due to inclusion of PEG 400 when the dry mix materials were at $25^{\circ} \mathrm{C}$

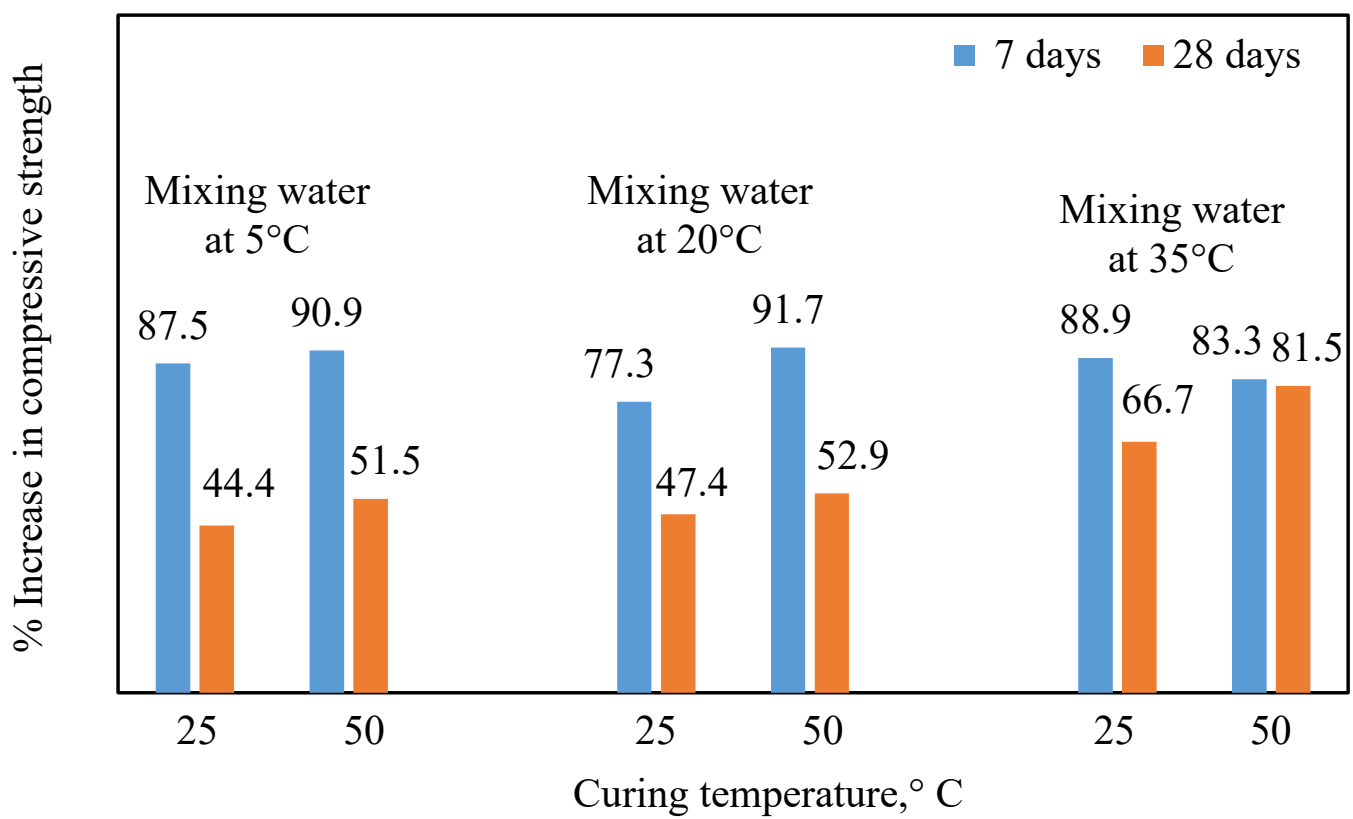

Figure 2 Percentage increase in compressive strength due to inclusion of PEG 400 when the dry mix materials were at $50^{\circ} \mathrm{C}$ 


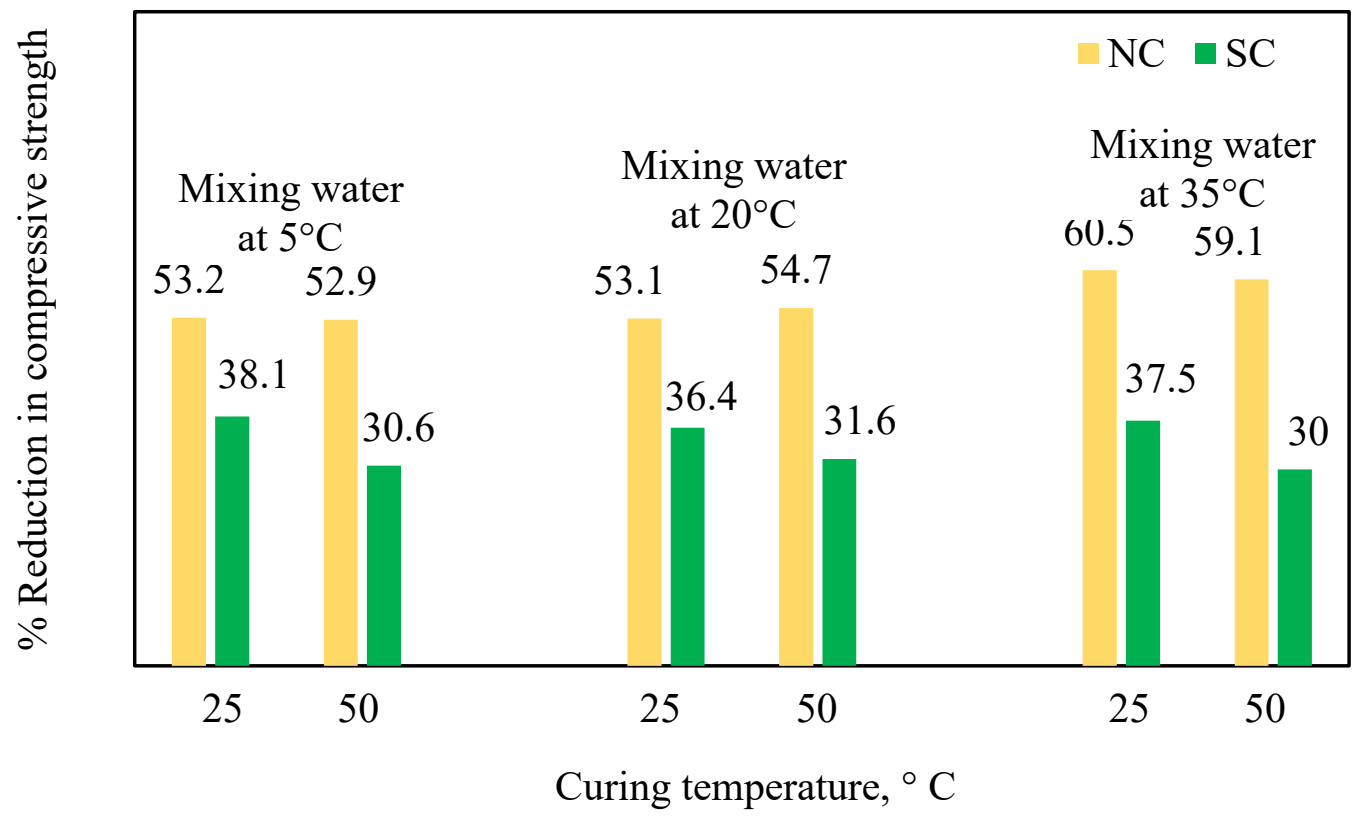

Figure 3 Percentage reduction in compressive strength at 28 days for samples with and without PEG 400 when the dry materials temperature increased from 25 to $50^{\circ} \mathrm{C}$.
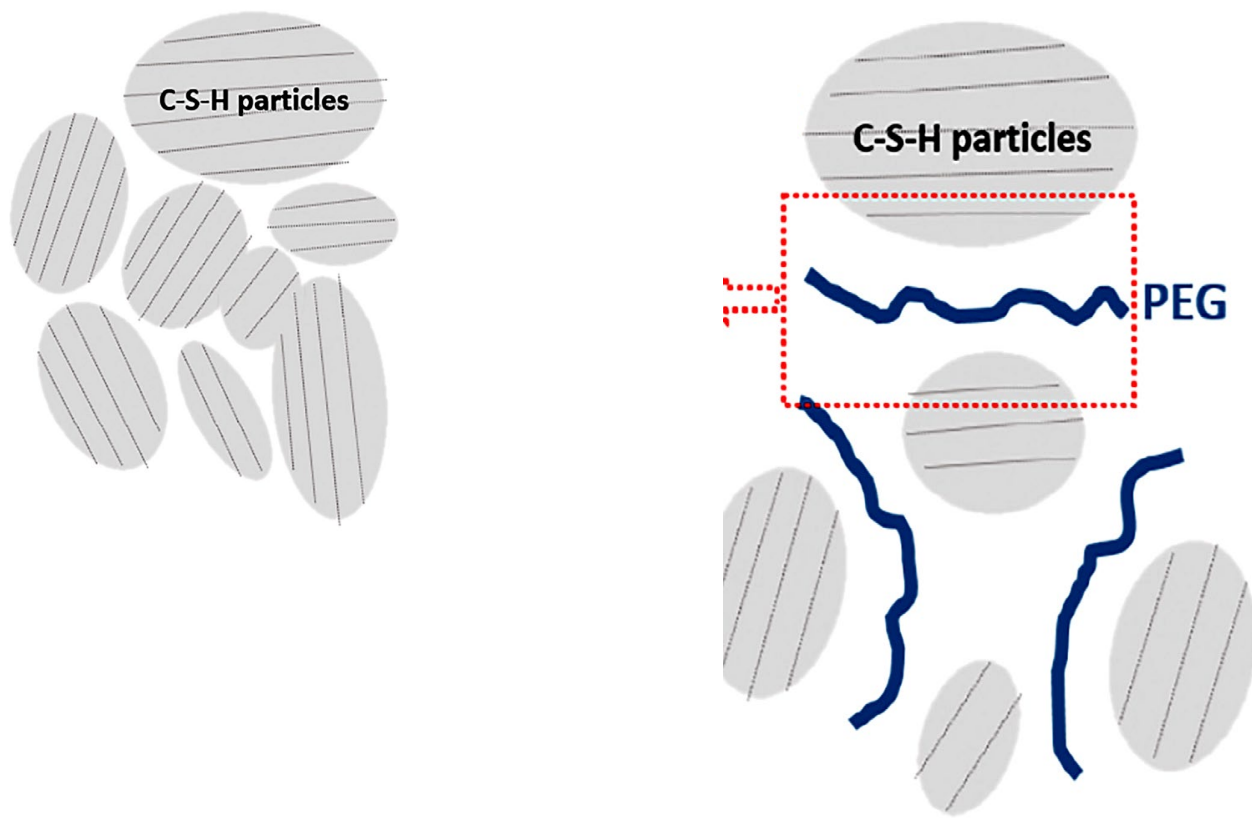

Figure 4 Model for staking of C-S-H, to the left without PEG 400 and to the right with PEG 400 based on Zhou et al. [68]. 
Table 1 Physical and mechanical properties of sand used

\begin{tabular}{cc}
\hline Description & Value \\
\hline Specific weight, $\mathrm{kg} / \mathrm{m}^{3}$ & 1730 \\
\hline Specific gravity & 2.63 \\
\hline Absorption $(\%)$ & 0.78 \\
\hline Voids ratio $(\%)$ & 33.81 \\
\hline Fineness modulus & 2.71 \\
\hline
\end{tabular}

Table 2 Grading of natural sand used and fine aggregate according to ASTM.C-33 (2003)

\begin{tabular}{cccccccc}
\hline Sieve size, $\mathrm{mm}$ & 9.5 & 4.75 & 2.36 & 1.18 & 0.61 & 0.31 & 0.16 \\
\hline Passing of sand used, $\%$ & 100 & 100 & 94 & 80 & 50 & 15 & 0 \\
\hline Passing (ASTM C33), $\%$ & 100 & $95-100$ & $80-100$ & $50-85$ & $25-60$ & $5-30$ & $0-10$ \\
\hline
\end{tabular}

Table 3 Physical and mechanical properties of dolomite used.

\begin{tabular}{|c|c|c|c|}
\hline Description & Value & Limit & \multirow{4}{*}{$\begin{array}{l}\text { Limits according to } \\
\text { ASTM.C-33 (2003) }\end{array}$} \\
\hline Specific Gravity & 2.64 & $2.6-2.7$ & \\
\hline Absorption, $\%$ & 0.76 & $\leq 1 \%$ & \\
\hline $\begin{array}{l}\text { Aggregate crushing } \\
\text { value }(A C V)\end{array}$ & $17.5 \%$ & $\leq 30 \%$ & \\
\hline
\end{tabular}

Table 4 Grading for natural dolomite used and coarse aggregate according to ASTM.C-33 (2003)

\begin{tabular}{lccccc}
\hline Sieve size, $\mathrm{mm}$ & 25 & 19 & 9.5 & 4.75 & 2.36 \\
\hline Passing of dolomite used, $\%$ & 100 & 98 & 25 & 1 & 1 \\
\hline Passing (ASTM C33), $\%$ & 100 & $90-100$ & $20-55$ & $0-10$ & $0-5$ \\
\hline
\end{tabular}

Table 5 Technical information of polyethylene glycol (PEG), as provided by the manufacturer

\begin{tabular}{cccccccc}
\hline $\begin{array}{c}\text { Average } \\
\text { molecular } \\
\text { weight }\end{array}$ & $\begin{array}{c}\text { Hydroxyl } \\
\text { Number, } \\
\mathrm{mg} \\
\mathrm{KOH} / \mathrm{g}\end{array}$ & $\begin{array}{c}\text { Liquid } \\
\text { Density } \\
\text { g/cc } \\
20^{\circ} \mathrm{C}\end{array}$ & $\begin{array}{c}\mathrm{PH} \text { at } \\
25^{\circ} \mathrm{C}, 5 \% \\
\text { Aqueous } \\
\text { solution }\end{array}$ & $\begin{array}{c}\text { Average } \\
\text { Number of } \\
\text { Repeating } \\
\text { Ox ethylene }\end{array}$ & $\begin{array}{c}\text { Melting } \\
\text { or } \\
\text { Freezing } \\
\text { range }{ }^{\circ} \mathrm{C}\end{array}$ & $\begin{array}{c}\text { Solubility } \\
\text { in water at } \\
20^{\circ} \mathrm{C}, \% \\
\text { by weight }\end{array}$ & $\begin{array}{c}\text { Viscosity } \\
\text { at } 100{ }^{\circ} \mathrm{C}\end{array}$ \\
\hline 380 to 420 & 264 to 300 & 1.1255 & $4.5-7.5$ & 8.7 & 4 to 8 & Complete & 7.3 \\
\hline
\end{tabular}


Table 6 Conventional and self-curing mix proportions batch quantities

\begin{tabular}{ccccccc}
\hline $\begin{array}{c}\text { Concrete } \\
\text { ingredients }\end{array}$ & Cement & Water & w/c* & $\begin{array}{c}\text { Coarse } \\
\text { aggregate }\end{array}$ & $\begin{array}{c}\text { Fine } \\
\text { aggregate }\end{array}$ & $\begin{array}{c}\text { PEG as self- } \\
\text { curing agent } \\
(\%)^{* *}\end{array}$ \\
\hline $\begin{array}{c}\text { Conventional } \\
\text { Mixes (NC) }\end{array}$ & 450 & 155 & 0.4 & 1172 & 614 & -- \\
\hline $\begin{array}{c}\text { Self-curing } \\
\text { Mixes (SC) }\end{array}$ & 450 & 149 & $\begin{array}{c}0.4 \\
\text { effective }\end{array}$ & 1172 & 614 & 1.5 \\
\hline
\end{tabular}

*By weight

**PEG 400 replaced mixing water to maintain effective $\mathrm{w} / \mathrm{c}$ constant

Table 7 Slump values for conventional NC and self-curing SC concrete

\begin{tabular}{ccc}
\hline $\begin{array}{c}\text { Type/Dry } \\
\text { Materials } \\
\text { Temperature }\end{array}$ & $\begin{array}{c}\text { Mixing water } \\
\text { temperature }\end{array}$ & Slump (mm) \\
\hline $\mathrm{NC} / 25^{\circ} \mathrm{C}$ & $20^{0} \mathrm{C}$ & 130 \\
& $35^{0} \mathrm{C}$ & 110 \\
\hline $\mathrm{SC} / 25^{\circ} \mathrm{C}$ & $5^{0} \mathrm{C}$ & 140 \\
& $20^{0} \mathrm{C}$ & 165 \\
& $35^{0} \mathrm{C}$ & 125 \\
\hline $\mathrm{NC} / 50^{\circ} \mathrm{C}$ & $5^{0} \mathrm{C}$ & 45 \\
& $20^{0} \mathrm{C}$ & 55 \\
& $35^{\circ} \mathrm{C}$ & 25 \\
\hline $\mathrm{SC} / 50^{\circ} \mathrm{C}$ & $5^{0} \mathrm{C}$ & 50 \\
& $20^{\circ} \mathrm{C}$ & 65 \\
& $35^{0} \mathrm{C}$ & 35 \\
\hline
\end{tabular}


Table 8 Development of compressive strength with time for NC, SC specimens when dry materials temperature was $25^{\circ} \mathrm{C}$

\begin{tabular}{|c|c|c|c|c|c|c|c|c|c|c|c|c|c|c|}
\hline \multirow{3}{*}{ 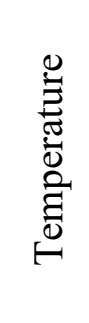 } & \multicolumn{6}{|c|}{ Dry Materials } & \multicolumn{4}{|c|}{$25^{0} \mathrm{C}$} & & & & \\
\hline & \multicolumn{2}{|c|}{ Mixing Water } & \multicolumn{4}{|c|}{$5^{0} \mathrm{C}$} & \multicolumn{4}{|c|}{$20^{\circ} \mathrm{C}$} & \multicolumn{4}{|c|}{$35^{0} \mathrm{C}$} \\
\hline & \multicolumn{2}{|c|}{ Curing } & \multicolumn{2}{|c|}{$25^{0} \mathrm{C}$} & \multicolumn{2}{|c|}{$50^{0} \mathrm{C}$} & \multicolumn{2}{|c|}{$25^{0} \mathrm{C}$} & \multicolumn{2}{|c|}{$50^{\circ} \mathrm{C}$} & \multicolumn{2}{|c|}{$25^{0} \mathrm{C}$} & \multicolumn{2}{|c|}{$50^{\circ} \mathrm{C}$} \\
\hline & $\begin{array}{l}\text { ncrete } \\
\text { /mix }\end{array}$ & Age & $\mathrm{NC}$ & $\mathrm{SC}$ & $\mathrm{NC}$ & $\mathrm{SC}$ & $\mathrm{NC}$ & $\mathrm{SC}$ & $\mathrm{NC}$ & $\mathrm{SC}$ & $\mathrm{NC}$ & $\mathrm{SC}$ & $\mathrm{NC}$ & $\mathrm{SC}$ \\
\hline \multirow{2}{*}{\multicolumn{2}{|c|}{$\begin{array}{c}\text { Compressive } \\
\text { strength } \\
\text { (MPa) at age } \\
\text { (days) }\end{array}$}} & 7 & 21 & 23.5 & 27 & 29 & 27 & 28.5 & 30 & 32 & 28 & 30 & 31.5 & 32.5 \\
\hline & & 28 & 38.5 & 42 & 35 & 36 & 40.5 & 44 & 37.5 & 38 & 38 & 40 & 33 & 35 \\
\hline
\end{tabular}

Table 9 Development of compressive strength with time for NC, SC specimens when dry materials temperature was $50^{\circ} \mathrm{C}$

\begin{tabular}{|c|c|c|c|c|c|c|c|c|c|c|c|c|c|c|}
\hline \multirow{3}{*}{ 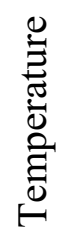 } & \multicolumn{6}{|c|}{ Dry Materials } & \multicolumn{4}{|c|}{$50^{0} \mathrm{C}$} & & & & \\
\hline & \multicolumn{2}{|c|}{ Mixing Water } & \multicolumn{4}{|c|}{$5^{0} \mathrm{C}$} & \multicolumn{4}{|c|}{$20^{\circ} \mathrm{C}$} & \multicolumn{4}{|c|}{$35^{0} \mathrm{C}$} \\
\hline & \multicolumn{2}{|l|}{ Curing } & \multicolumn{2}{|c|}{$25^{0} \mathrm{C}$} & \multicolumn{2}{|c|}{$50^{0} \mathrm{C}$} & \multicolumn{2}{|c|}{$25^{0} \mathrm{C}$} & \multicolumn{2}{|c|}{$50^{\circ} \mathrm{C}$} & \multicolumn{2}{|c|}{$25^{0} \mathrm{C}$} & \multicolumn{2}{|c|}{$50^{0} \mathrm{C}$} \\
\hline & $\begin{array}{l}\text { Concrete } \\
\text { age/mix }\end{array}$ & Age & $\mathrm{NC}$ & $\mathrm{SC}$ & $\mathrm{NC}$ & $\mathrm{SC}$ & $\mathrm{NC}$ & $\mathrm{SC}$ & $\mathrm{NC}$ & $\mathrm{SC}$ & $\mathrm{NC}$ & $\mathrm{SC}$ & $\mathrm{NC}$ & $\mathrm{SC}$ \\
\hline \multirow{2}{*}{\multicolumn{2}{|c|}{$\begin{array}{l}\text { Compressive } \\
\text { strength (MPa) } \\
\text { at age (days) }\end{array}$}} & 7 & 8 & 15 & 11 & 21 & 11 & 19.5 & 12 & 23 & 9 & 17 & 12 & 22 \\
\hline & & 28 & 18 & 26 & 16.5 & 25 & 19 & 28 & 17 & 26 & 15 & 25 & 13.5 & 24.5 \\
\hline
\end{tabular}


Table 10 Percentage change in compressive strength due to increasing mixing water temperature

\begin{tabular}{|c|c|c|c|c|c|c|c|c|c|c|c|c|c|}
\hline \multirow{3}{*}{ 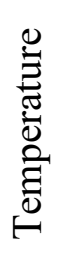 } & \multicolumn{5}{|c|}{ Dry Materials } & \multicolumn{4}{|c|}{$25^{0} \mathrm{C}$} & & & & \\
\hline & \multicolumn{2}{|c|}{ Mixing Water } & \multicolumn{3}{|c|}{$5^{0} \mathrm{C}$} & \multicolumn{4}{|c|}{$20^{\circ} \mathrm{C}$} & \multicolumn{4}{|c|}{$35^{0} \mathrm{C}$} \\
\hline & \multicolumn{2}{|l|}{ Curing } & \multicolumn{2}{|l|}{$25^{0} \mathrm{C}$} & $50^{0} \mathrm{C}$ & \multicolumn{2}{|c|}{$25^{0} \mathrm{C}$} & \multicolumn{2}{|c|}{$50^{\circ} \mathrm{C}$} & \multicolumn{2}{|c|}{$25^{0} \mathrm{C}$} & \multicolumn{2}{|c|}{$50^{\circ} \mathrm{C}$} \\
\hline \multicolumn{2}{|c|}{$\begin{array}{l}\text { Concrete } \\
\text { age/mix }\end{array}$} & Age & & & & $\mathrm{NC}$ & $\mathrm{SC}$ & $\mathrm{NC}$ & $\mathrm{SC}$ & $\mathrm{NC}$ & $\mathrm{SC}$ & $\mathrm{NC}$ & $\mathrm{SC}$ \\
\hline \multirow{2}{*}{\multicolumn{2}{|c|}{$\begin{array}{l}\text { Percentage } \\
\text { change at age } \\
\text { (days) }\end{array}$}} & 7 & - & - & - & 28.6 & 21.3 & 11.1 & 10.3 & 33.3 & 27.7 & 16.7 & 12.1 \\
\hline & & 28 & - & - & - & 5.2 & 4.8 & 7.1 & 5.6 & -1.3 & -4.8 & -5.7 & -2.8 \\
\hline \multirow{3}{*}{ 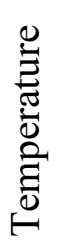 } & \multicolumn{2}{|c|}{ Dry Materials } & & & & \multicolumn{4}{|c|}{$50^{0} \mathrm{C}$} & & & & \\
\hline & \multicolumn{2}{|c|}{ Mixing Water } & \multicolumn{3}{|c|}{$5^{0} \mathrm{C}$} & \multicolumn{4}{|c|}{$20^{\circ} \mathrm{C}$} & \multicolumn{4}{|c|}{$35^{0} \mathrm{C}$} \\
\hline & \multicolumn{2}{|l|}{ Curing } & \multicolumn{2}{|c|}{$25^{0} \mathrm{C}$} & $50^{0} \mathrm{C}$ & \multicolumn{2}{|c|}{$25^{0} \mathrm{C}$} & \multicolumn{2}{|c|}{$50^{\circ} \mathrm{C}$} & \multicolumn{2}{|c|}{$25^{\circ} \mathrm{C}$} & \multicolumn{2}{|c|}{$50^{\circ} \mathrm{C}$} \\
\hline & $\begin{array}{l}\text { Concrete } \\
\text { age/mix }\end{array}$ & Age & & & & $\mathrm{NC}$ & $\mathrm{SC}$ & $\mathrm{NC}$ & $\mathrm{SC}$ & $\mathrm{NC}$ & $\mathrm{SC}$ & $\mathrm{NC}$ & $\mathrm{SC}$ \\
\hline \multirow{2}{*}{\multicolumn{2}{|c|}{$\begin{array}{c}\text { Percentage } \\
\text { Change at age } \\
\text { (days) }\end{array}$}} & 7 & - & - & - & 37.5 & 30 & 9.1 & 9.5 & 12.5 & 13.3 & 9.1 & 4.8 \\
\hline & & 28 & - & - & - & 5.6 & 7.7 & 3 & 4 & -16.7 & -3.8 & -18.1 & -2 \\
\hline
\end{tabular}


Table 11 Ratio of compressive strength when the curing temperature is $50^{\circ} \mathrm{C}$ to that when the curing temperature is $25^{0} \mathrm{C}$

\begin{tabular}{|c|c|c|c|c|c|c|c|c|c|c|c|c|c|c|}
\hline \multirow{3}{*}{ 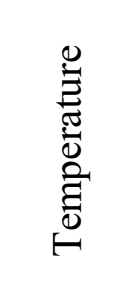 } & \multicolumn{6}{|c|}{ Dry Materials } & \multicolumn{4}{|c|}{$25^{0} \mathrm{C}$} & & & & \\
\hline & \multicolumn{2}{|c|}{$\begin{array}{l}\text { Mixing } \\
\text { Water }\end{array}$} & \multicolumn{4}{|c|}{$5^{0} \mathrm{C}$} & \multicolumn{4}{|c|}{$20^{\circ} \mathrm{C}$} & \multicolumn{4}{|c|}{$35^{0} \mathrm{C}$} \\
\hline & \multicolumn{2}{|c|}{ Curing } & \multicolumn{2}{|c|}{$25^{0} \mathrm{C}$} & \multicolumn{2}{|c|}{$50^{\circ} \mathrm{C}$} & \multicolumn{2}{|c|}{$25^{0} \mathrm{C}$} & \multicolumn{2}{|c|}{$50^{0} \mathrm{C}$} & \multicolumn{2}{|c|}{$25^{0} \mathrm{C}$} & \multicolumn{2}{|c|}{$50^{0} \mathrm{C}$} \\
\hline \multicolumn{2}{|c|}{$\begin{array}{l}\text { Concrete } \\
\text { age/mix }\end{array}$} & Age & $\mathrm{NC}$ & $\mathrm{SC}$ & $\mathrm{NC}$ & $\mathrm{SC}$ & $\mathrm{NC}$ & $\mathrm{SC}$ & $\mathrm{NC}$ & $\mathrm{SC}$ & $\mathrm{NC}$ & $\mathrm{SC}$ & $\mathrm{NC}$ & $\mathrm{SC}$ \\
\hline \multirow{2}{*}{\multicolumn{2}{|c|}{$\begin{array}{c}\text { Ratio of } \\
\text { Compressive } \\
\text { strength at age } \\
\text { (days) }\end{array}$}} & 7 & - & - & 1.29 & 1.23 & - & - & 1.11 & 1.12 & - & - & 1.13 & 1.08 \\
\hline & & 28 & - & - & 0.91 & 0.86 & - & - & 0.93 & 0.86 & - & - & 0.87 & 0.88 \\
\hline \multirow{3}{*}{ 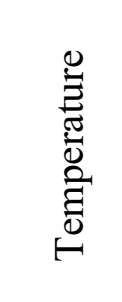 } & \multicolumn{2}{|c|}{ Dry Materials } & & & & & \multicolumn{4}{|c|}{$50^{\circ} \mathrm{C}$} & & & & \\
\hline & \multicolumn{2}{|c|}{$\begin{array}{l}\text { Mixing } \\
\text { Water }\end{array}$} & \multicolumn{4}{|c|}{$5^{0} \mathrm{C}$} & \multicolumn{4}{|c|}{$20^{\circ} \mathrm{C}$} & \multicolumn{4}{|c|}{$35^{0} \mathrm{C}$} \\
\hline & \multicolumn{2}{|c|}{ Curing } & \multicolumn{2}{|c|}{$25^{0} \mathrm{C}$} & \multicolumn{2}{|c|}{$50^{\circ} \mathrm{C}$} & \multicolumn{2}{|c|}{$25^{0} \mathrm{C}$} & \multicolumn{2}{|c|}{$50^{\circ} \mathrm{C}$} & \multicolumn{2}{|c|}{$25^{0} \mathrm{C}$} & \multicolumn{2}{|c|}{$50^{\circ} \mathrm{C}$} \\
\hline \multicolumn{2}{|c|}{$\begin{array}{l}\text { Concrete } \\
\text { age/mix }\end{array}$} & Age & $\mathrm{NC}$ & $\mathrm{SC}$ & $\mathrm{NC}$ & $\mathrm{SC}$ & $\mathrm{NC}$ & $\mathrm{SC}$ & $\mathrm{NC}$ & $\mathrm{SC}$ & $\mathrm{NC}$ & $\mathrm{SC}$ & $\mathrm{NC}$ & $\mathrm{SC}$ \\
\hline \multirow{2}{*}{\multicolumn{2}{|c|}{$\begin{array}{c}\text { Ratio of } \\
\text { Compressive } \\
\text { strength at age } \\
\text { (days) }\end{array}$}} & 7 & - & - & 1.38 & 1.4 & - & - & 1.09 & 1.18 & - & - & 1.33 & 1.29 \\
\hline & & 28 & - & - & 0.92 & 0.96 & - & - & 0.89 & 0.93 & - & - & 0.90 & 0.98 \\
\hline
\end{tabular}


Table 12 Splitting tensile strength for NC and SC specimens at 28 days for different mixing water temperatures when dry materials temperature was $25^{\circ} \mathrm{C}$ or $50^{\circ} \mathrm{C}$

\begin{tabular}{|c|c|c|c|c|c|c|c|c|c|c|c|c|c|}
\hline \multirow{3}{*}{ 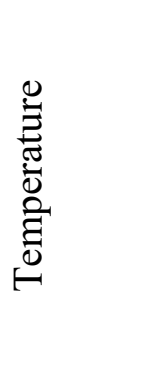 } & $\begin{array}{c}\text { Mixing } \\
\text { water }\end{array}$ & \multicolumn{4}{|c|}{$5^{0} \mathrm{C}$} & \multicolumn{4}{|c|}{$20^{\circ} \mathrm{C}$} & \multicolumn{4}{|c|}{$35^{0} \mathrm{C}$} \\
\hline & Curing & \multicolumn{2}{|c|}{$25^{0} \mathrm{C}$} & \multicolumn{2}{|c|}{$50^{\circ} \mathrm{C}$} & \multicolumn{2}{|c|}{$25^{0} \mathrm{C}$} & \multicolumn{2}{|c|}{$50^{\circ} \mathrm{C}$} & \multicolumn{2}{|c|}{$25^{\circ} \mathrm{C}$} & \multicolumn{2}{|c|}{$50^{\circ} \mathrm{C}$} \\
\hline & $\begin{array}{c}\text { Dry } \\
\text { material } \\
\mathrm{s}\end{array}$ & $\mathrm{NC}$ & $\mathrm{SC}$ & $\mathrm{NC}$ & $\mathrm{SC}$ & $\mathrm{NC}$ & $\mathrm{SC}$ & $\mathrm{NC}$ & $\mathrm{SC}$ & $\mathrm{NC}$ & $\mathrm{SC}$ & $\mathrm{NC}$ & $\mathrm{SC}$ \\
\hline $\begin{array}{c}\text { Splitting } \\
\text { Tensile }\end{array}$ & $25^{0} \mathrm{C}$ & 3.4 & 3.9 & 2.9 & 3.6 & 3.7 & 4.1 & 3.4 & 3.9 & 3.2 & 3.7 & 2.8 & 3.4 \\
\hline $\begin{array}{c}\text { Strength } \\
(\mathrm{MPa})\end{array}$ & $50^{\circ} \mathrm{C}$ & 2.5 & 3.3 & 2 & 2.8 & 2.9 & 3.4 & 2.2 & 2.9 & 2.3 & 3 & 1.8 & 2.7 \\
\hline
\end{tabular}

Table 13 Effect of PEG 400 inclusion on the Tensile Strength of Concrete

\begin{tabular}{|c|c|c|c|c|c|c|c|c|c|c|c|c|c|}
\hline \multirow{3}{*}{ 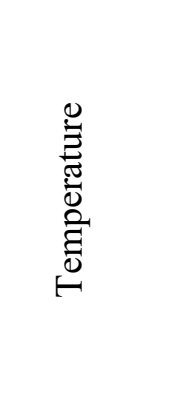 } & $\begin{array}{l}\text { Mixing } \\
\text { water }\end{array}$ & \multicolumn{4}{|c|}{$5^{0} \mathrm{C}$} & \multicolumn{4}{|c|}{$20^{\circ} \mathrm{C}$} & \multicolumn{4}{|c|}{$35^{\circ} \mathrm{C}$} \\
\hline & \multirow{2}{*}{$\begin{array}{c}\text { Curing } \\
\begin{array}{c}\text { Dry } \\
\text { materials }\end{array}\end{array}$} & \multicolumn{2}{|c|}{$25^{0} \mathrm{C}$} & \multicolumn{2}{|c|}{$50^{\circ} \mathrm{C}$} & \multicolumn{2}{|c|}{$25^{\circ} \mathrm{C}$} & \multicolumn{2}{|c|}{$50^{\circ} \mathrm{C}$} & \multicolumn{2}{|c|}{$25^{0} \mathrm{C}$} & \multicolumn{2}{|c|}{$50^{\circ} \mathrm{C}$} \\
\hline & & $\mathrm{NC}$ & $\mathrm{SC}$ & $\mathrm{NC}$ & $\mathrm{SC}$ & $\mathrm{NC}$ & $\mathrm{SC}$ & $\mathrm{NC}$ & $\mathrm{SC}$ & $\mathrm{NC}$ & $\mathrm{SC}$ & $\mathrm{NC}$ & $\mathrm{SC}$ \\
\hline $\begin{array}{c}\text { Increase in } \\
\text { Splitting }\end{array}$ & $25^{\circ} \mathrm{C}$ & - & 14.7 & - & 24.1 & - & 10.8 & - & 14.7 & - & 15.6 & - & 21.4 \\
\hline $\begin{array}{l}\text { Strength } \\
\text { (MPa) }\end{array}$ & $50^{\circ} \mathrm{C}$ & - & 32 & - & 40 & - & 17.2 & - & 31.8 & - & 30.4 & - & 42.1 \\
\hline
\end{tabular}


Table 14 Effect of increase of dry materials temperature from 25 to $50^{\circ} \mathrm{C}$ on the splitting tensile strength of the concrete

\begin{tabular}{|c|c|c|c|c|c|c|c|c|c|c|c|c|c|}
\hline \multirow{2}{*}{ 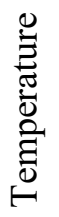 } & \multirow{2}{*}{ 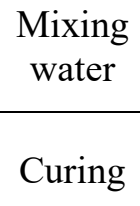 } & \multicolumn{4}{|c|}{$5^{0} \mathrm{C}$} & \multicolumn{4}{|c|}{$20^{\circ} \mathrm{C}$} & \multicolumn{4}{|c|}{$35^{\circ} \mathrm{C}$} \\
\hline & & \multicolumn{2}{|c|}{$25^{0} \mathrm{C}$} & \multicolumn{2}{|c|}{$50^{\circ} \mathrm{C}$} & \multicolumn{2}{|c|}{$25^{\circ} \mathrm{C}$} & \multicolumn{2}{|c|}{$50^{\circ} \mathrm{C}$} & \multicolumn{2}{|c|}{$25^{\circ} \mathrm{C}$} & \multicolumn{2}{|c|}{$50^{\circ} \mathrm{C}$} \\
\hline & te type & $\mathrm{NC}$ & $\mathrm{SC}$ & $\mathrm{NC}$ & $\mathrm{SC}$ & $\mathrm{NC}$ & $\mathrm{SC}$ & $\mathrm{NC}$ & $\mathrm{SC}$ & $\mathrm{NC}$ & $\mathrm{SC}$ & $\mathrm{NC}$ & $\mathrm{SC}$ \\
\hline & $\begin{array}{l}\text { ction in } \\
\text { Tensile } \\
\text { ggth }\end{array}$ & -26.5 & -15.4 & -31 & -22.2 & -21.6 & -17.1 & -35.3 & -25.6 & -28.1 & -18.9 & -35.7 & -20.6 \\
\hline
\end{tabular}

Table 15 Flexure strength for $\mathrm{NC}$ and SC specimens at 28 days for different mixing water temperatures when dry materials temperature was $25^{\circ} \mathrm{C}$ or $50^{\circ} \mathrm{C}$

\begin{tabular}{|c|c|c|c|c|c|c|c|c|c|c|c|c|c|}
\hline \multirow{3}{*}{ 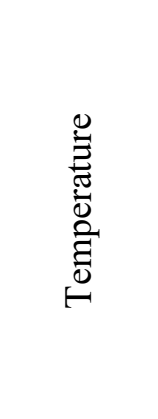 } & Mixing & \multicolumn{4}{|c|}{$5^{0} \mathrm{C}$} & \multicolumn{4}{|c|}{$20^{\circ} \mathrm{C}$} & \multicolumn{4}{|c|}{$35^{\circ} \mathrm{C}$} \\
\hline & \multirow{2}{*}{$\begin{array}{c}\text { Curing } \\
\begin{array}{c}\text { Dry } \\
\text { materials }\end{array}\end{array}$} & \multicolumn{2}{|c|}{$25^{0} \mathrm{C}$} & \multicolumn{2}{|c|}{$50^{\circ} \mathrm{C}$} & \multicolumn{2}{|c|}{$25^{0} \mathrm{C}$} & \multicolumn{2}{|c|}{$50^{\circ} \mathrm{C}$} & \multicolumn{2}{|c|}{$25^{0} \mathrm{C}$} & \multicolumn{2}{|c|}{$50^{\circ} \mathrm{C}$} \\
\hline & & $\mathrm{NC}$ & $\mathrm{SC}$ & $\mathrm{NC}$ & $\mathrm{SC}$ & $\mathrm{NC}$ & $\mathrm{SC}$ & $\mathrm{NC}$ & $\mathrm{SC}$ & $\mathrm{NC}$ & $\mathrm{SC}$ & $\mathrm{NC}$ & $\mathrm{SC}$ \\
\hline \multirow{2}{*}{$\begin{array}{c}\text { Flexural } \\
\text { Strength } \\
(\mathrm{MPa})\end{array}$} & $25^{\circ} \mathrm{C}$ & 5.3 & 5.7 & 4.7 & 5 & 5.4 & 5.6 & 5.3 & 5.4 & 5.3 & 5.4 & 4.8 & 5 \\
\hline & $50^{\circ} \mathrm{C}$ & 4.9 & 5.3 & 4.2 & 4.7 & 5 & 5.4 & 4.9 & 5.1 & 4.8 & 5.1 & 4.6 & 4.8 \\
\hline
\end{tabular}

